\title{
Molecular Targets of Epigallocatechin-Gallate (EGCG): A Special Focus on Signal Transduction and Cancer
}

\author{
Aide Negri ${ }^{1,+}$, Valeria Naponelli ${ }^{1,2, *,+}$, , Federica Rizzi ${ }^{1,2,3}$ and Saverio Bettuzzi ${ }^{1,2,3}$ \\ 1 Department of Medicine and Surgery, University of Parma, Via Gramsci 14, 43126 Parma, Italy; \\ aide.negri@unipr.it (A.N.); federica.rizzi@unipr.it (F.R.); saverio.bettuzzi@unipr.it (S.B.) \\ 2 National Institute of Biostructure and Biosystems (INBB), Viale Medaglie d'Oro 305, 00136 Rome, Italy \\ 3 Centre for Molecular and Translational Oncology (COMT), University of Parma, Parco Area delle Scienze \\ 11/a, 43124 Parma, Italy \\ * Correspondence: valeria.naponelli@unipr.it; Tel.: +39-0521-033790 \\ + These authors contributed equally to this work.
}

Received: 7 November 2018; Accepted: 4 December 2018; Published: 6 December 2018

\begin{abstract}
Green tea is a beverage that is widely consumed worldwide and is believed to exert effects on different diseases, including cancer. The major components of green tea are catechins, a family of polyphenols. Among them, epigallocatechin-gallate (EGCG) is the most abundant and biologically active. EGCG is widely studied for its anti-cancer properties. However, the cellular and molecular mechanisms explaining its action have not been completely understood, yet. EGCG is effective in vivo at micromolar concentrations, suggesting that its action is mediated by interaction with specific targets that are involved in the regulation of crucial steps of cell proliferation, survival, and metastatic spread. Recently, several proteins have been identified as EGCG direct interactors. Among them, the trans-membrane receptor 67LR has been identified as a high affinity EGCG receptor. 67LR is a master regulator of many pathways affecting cell proliferation or apoptosis, also regulating cancer stem cells (CSCs) activity. EGCG was also found to be interacting directly with Pin1, TGFR-II, and metalloproteinases (MMPs) (mainly MMP2 and MMP9), which respectively regulate EGCG-dependent inhibition of NF-kB, epithelial-mesenchimal transaction (EMT) and cellular invasion. EGCG interacts with DNA methyltransferases (DNMTs) and histone deacetylases (HDACs), which modulates epigenetic changes. The bulk of this novel knowledge provides information about the mechanisms of action of EGCG and may explain its onco-suppressive function. The identification of crucial signalling pathways that are related to cancer onset and progression whose master regulators interacts with EGCG may disclose intriguing pharmacological targets, and eventually lead to novel combined treatments in which EGCG acts synergistically with known drugs.
\end{abstract}

Keywords: green tea catechins; epigallocatechin-gallate (EGCG); 67LR; cancer apoptosis; cell death; chemoprevention; gene expression

\section{Introduction}

Green tea is produced from Camellia sinensis and it represents the second most consumed beverage in the world after water, being used primarily in Asia and in the Middle East [1].

Several observational and intervention studies have demonstrated that green tea consumption has beneficial effects on many human diseases, including obesity, metabolic syndrome, neurodegenerative disorders inflammatory diseases, and cancer [2-6]. The major polyphenolic component of dried green tea extracts is epigallocatechin-gallate (EGCG) EGCG is the most abundant and biologically active catechin from green tea, accounting for at least $50 \%$ of the total catechin content in green tea leaves [7]. 
The biological effects of green tea were initially ascribed to pro- or anti-oxidative properties of catechins. Most of the studies have been conducted administrating green tea extracts or pure EGCG. A typical weakness of many studies is related to data collected in vitro and cell culture systems, following the administration of doses of green tea extracts (or EGCG) much higher than those that were reached in human plasma after green tea consumption. In vivo, administration of the equivalent of two or three cups of green tea leads to a peak in the plasma levels of tea catechins in the sub-micromolar range in humans [8,9].

Several in vitro, in vivo, and clinical studies have shown multiple EGCG anticancer actions. Among them there are anti-proliferative, pro-apoptotic, anti-angiogenic, and anti-invasive functions [10]. Furthermore, EGCG has been observed to impair other processes that are involved in carcinogenesis as inflammation, oxidative stress and hypoxia and to target tumor microenviroment components (e.g., cancer stem cells, fibroblasts, macrophages, and microvasculature) [11]. In several in vitro and in vivo cancer types, EGCG has been shown to act synergistically with other natural compounds (e.g., curcumin, ascorbic acid, quercetin, genestein, caffeine) $[10,12]$ and it has also been testing in combination with currently used chemotherapeutic drugs (e.g., doxorubicin, cisplatin, sunitinib) [13-16]. Furthermore, in order to improve EGCG bioavailability and stability, novel formulations of the catechin encapsulated in nanoparticles have been developed [17-20].

Even if the anti-tumoural effect of green tea catechins (and specifically EGCG) has been extensively demonstrated in vitro, their molecular and cellular mechanisms are not yet completely understood [21,22].

The anti-cancer effect of EGCG and green tea extracts is mediated through several mechanisms, including stimulation of anti-oxidant activity and activation of detoxification system [23,24], alteration of the cell cycle [25], suppression of mitogen-activated protein kinase (MAPK) and receptor protein kinase (RTKs) pathways [26,27], inhibition of clonal expansion of the tumour-initiating stem cell population [28], and production of epigenetic changes in gene expression [29]. These mechanisms (reviewed recently in [30-32]) are not completely understood yet. Green tea catechins are thought to function both as powerful radical scavengers, in particular, under increased oxidative stress conditions [33], and as ROS generators leading to the inhibition of cancer cell growth through the induction of apoptotis [24,34]. Moreover, they have been shown to induce apoptosis in several ways, such as modulating pro- and anti-apoptotic protein (Bax, Bcl-2, Bcl-XL) and cell cycle regulator proteins (cyclins, CDKs) [35]. Green tea catechins are also able to target genes and proteins that are associated with cell proliferation and apoptosis, including RTKs (receptor tyrosine kinases). Several studies described the inhibitory effect of green tea catechins on these receptors and on Ras/extracellular signal-regulated kinase (ERK)/MAPK and phosphatidylinositol 3-kinase (PI3K)/Akt, which are RTKs-related downstream pathways that are often constitutively activated in tumor cells. EGCG negatively modulates the expression of various transcription factors, including Sp1, AP-1, and NF-kB preventing cancer formation [36,37]. Another mechanism that can explain the pleiotropic effects exerted by green tea catechins is represented by the epigenetic changes in gene expression and chromatin organization. The major epigenetic mechanisms are DNA methylation, histone modifications, and expression of noncoding regulatory micro RNA (miRNAs). Green tea catechins can induce an epigenetic reactivation of genes silenced during carcinogenesis or an epigenetic downregulation of oncogenes through the inhibition of DNA methyltransferases (DNMTs) or histone deacetylases (HDACs) activity and the reduction of their expression $[38,39]$.

Micromolar concentrations of EGCG have been shown to exert a wide array of different effects in a cancer cell. The current understanding is that catechins may either interact with a single critical regulator affecting the activity of key enzymes that are involved in important pathways, or by hitting multiple targets in parallel, thereby modulating different pathways simultaneously [40,41].

First it is necessary to identify proteins that bind to catechins with high affinity, which may represent the master regulators controlling one or multiple pathways. Using in vitro models, several research teams have identified proteins that are targeted by EGCG. Among these are vimentin, Fyn, 
ZAP70, insulin-like growth factor 1 receptor, and glucose regulated protein $78 \mathrm{kDa}$ [42-46]. However, the functional effect of green tea catechins on the target protein activity has been demonstrated only at much higher concentrations of EGCG than Kd values, probably because of the non-specific binding of EGCG to other proteins competing for the target [47]. In Table 1 are listed the principal EGCG molecular targets that were identified in cancer cells.

We think that EGCG-protein binding can be important for the beneficial effect of green tea catechins. Green tea catechins bind to a plethora of proteins and the process of the interaction is highly dependent on the folding status and on the conformational properties of the target protein. In this review, we decided to take into consideration only few proteins that, after direct binding to EGCG, alter and affect their downstream pathways promoting anti-cancer effects. These data could be used for a rational drug design of green tea catechins derivatives exploitable for more specific and effective anti-cancer therapies. We will focus particularly on the onset and progression of cancer, describing and discussing the possible molecular mechanisms through which catechins exert their action.

Table 1. Epigallocatechin-gallate (EGCG) molecular targets that are involved in cancer onset and progression.

\begin{tabular}{|c|c|c|c|c|c|}
\hline $\begin{array}{c}\text { Cell Cycle, } \\
\text { Proliferation \& } \\
\text { Survival }\end{array}$ & $\begin{array}{l}\text { Apoptosis \& Cell } \\
\text { Death }\end{array}$ & $\begin{array}{c}\text { Motility, } \\
\text { Invasion and } \\
\text { Metastatization }\end{array}$ & Inflammation & $\begin{array}{l}\text { Epigenetic } \\
\text { Control }\end{array}$ & Others \\
\hline p16 [48] & Bax [49] & MMP-2 * [50] & FceRI [51] & DNMT1 * [39] & DAPK1 [52] \\
\hline p18 [35] & Bad [53] & MMP-9* [50] & IL-8 [54] & DNMT3A [48] & MRLC [55] \\
\hline p21 [48] & Bak [56] & MMP-14 [57] & IGF-1R * [45] & DNMT3B * [39] & MYPT1 [55] \\
\hline p27 [56] & $\mathrm{Bcl}-2 *[58]$ & uPA [59] & VEGF [60] & HDAC1 $*[39]$ & eEF1a [61] \\
\hline Cyclin D [56] & Bcl-xl [53] & PAI-1 [59] & CSF-1 [62] & HDAC2 [63] & ID1 [64] \\
\hline Cyclin E [35] & Bcl-xs [56] & E-cadherine [39] & CCL-2 [62] & HAT [65] & RAR- $\beta$ [39] \\
\hline Cyclin A [66] & Caspase3 [56] & SLUG [67] & COX-2 [60] & hTERT [68] & HSP70 [53] \\
\hline Cyclin B [66] & Caspase8 [69] & SNAIL1 [70] & iNOS [71] & EZH2 [72] & $\mathrm{HSP} 90 *[73]$ \\
\hline CDK4 [56] & Caspase9 [56] & Vimentin * [42] & eNOS [74-78] & & GRP78 * [46] \\
\hline CDK6 [56] & Apaf-1 [53] & Twist [79] & & & PECAM-1 [80] \\
\hline CDK2 [35] & Puma [56] & N-cadherine [79] & & & miR-16 [62] \\
\hline CDK1 [66] & XIAP [53] & HIF-1 $\alpha[60]$ & & & let-7b miRNA [81] \\
\hline Erk1/2 [56] & Cytochrome C [56] & $\beta$-catenin [54] & & & miR-210 [82] \\
\hline $\operatorname{Pin} *[83]$ & p53 [84] & Wnt [54] & & & miR34a [85] \\
\hline PPA2 [86] & Survivin [87] & TIMP-3 [72] & & & miR145 [85] \\
\hline PKA [86] & Fas [69] & & & & miR200c [85] \\
\hline STAT [12] & DR5 [69] & & & & ZAP70 * [44] \\
\hline $\mathrm{AR}[65]$ & PARP [88] & & & & TRAF-6 * [89] \\
\hline $67 \mathrm{LR} *[90]$ & & & & & Oct4 [85] \\
\hline FceRI [51] & & & & & Sox2 [91] \\
\hline EGFR [92] & & & & & Notch1 [85] \\
\hline HGFR [93] & & & & & Nanog [85] \\
\hline TGFR-II * [94] & & & & & CD133 [95] \\
\hline \multicolumn{6}{|l|}{ cGMP [74] [96] } \\
\hline \multicolumn{6}{|l|}{ cAMP [86] } \\
\hline \multicolumn{6}{|l|}{ P-glycoprotein [88] } \\
\hline \multicolumn{6}{|l|}{ NF-kB [97] } \\
\hline \multicolumn{6}{|l|}{ c-Myc [98] } \\
\hline \multicolumn{6}{|l|}{ FOXO3a [99] } \\
\hline \multicolumn{6}{|l|}{ GSK-3 $\beta$ [98] } \\
\hline \multicolumn{6}{|l|}{ PI3K [100] } \\
\hline \multicolumn{6}{|l|}{ AKT [100] } \\
\hline \multicolumn{6}{|l|}{ PKC- $\delta[74]$} \\
\hline \multicolumn{6}{|l|}{ JAK-1/2 [12] } \\
\hline \multicolumn{6}{|l|}{ Src [57] } \\
\hline \multicolumn{6}{|l|}{$\mathrm{CK} 1 \alpha[98]$} \\
\hline \multicolumn{6}{|l|}{ p38 MAPK [56] } \\
\hline JNK [56] & & & & & \\
\hline
\end{tabular}




\section{67-kDa Laminin Receptor Signalling Pathways}

One of the most interesting targets of EGCG action is the 67-kDa laminin receptor (67LR), a non-integrin cell surface receptor whose expression has been shown to be increased in several cancers, such as blood, prostate, breast, gastric, and colon [101-106]. The receptor expression is usually correlated with drug resistance, and it contributes positively to cancer cells viability, tumour progression, metastatic diffusion, and neo-angiogenesis [101,102,107,108].

In 2004, Tachibana et al. identified for the first time the 67LR as a specific EGCG membrane receptor using surface plasmon resonance. The study revealed that 67LR was able to bind EGCG with a $\mathrm{Kd}$ value of $39.9 \mathrm{nM}$. This interaction enabled EGCG to reduce the growth of the lung cancer cell line A549 [90], thus exerting anticancer activity. Other green tea components, such as caffeine, quercetin, epicatechin (EC), and epigallocatechin (EGC) were tested for binding to 67LR, but none were specific ligands of the receptor or showed tumour suppressive effects [90]. Therefore, EGCG appears to be the only catechin able to bind 67LR. Subsequently, a putative EGCG binding site corresponding to the region between the residues 161 and 170 of the receptor has been identified [109]. The direct binding between EGCG and 67LR has been confirmed in prostate cancer cells by Yu et al. [104]. Using MVD (Molegro Virtual Docker, an integrated platform for predicting protein ligand interactions), these authors identified a binding site for EGCG with the same sequence of the laminin tyrosine-isoleucine-glycine-serine-arginine (YIGSR) peptide, corresponding to the 929-933 sequence of $\beta 1$ chain of 67LR [104].

Many studies have explored the signalling cascades that are triggered by EGCG-67LR interaction, some of which will be discussed in this review. In many cases, the tumour suppression pathway affected ordered microdomains of the cell membrane known as lipid rafts, where the 67LR has been located [110]. Lipid rafts differ from the surrounding membrane, because their composition is enriched in specific lipids (sphingomyelins and glycosphingolipids) and cholesterol, which are tightly packed to form liquid ordered assemblies [111]. Lipid rafts are dynamic, heterogeneous structures whose composition is extremely variable, not only in relation to the lipid and sterols content, but also because of the several proteins that can be recruited (e.g., BCR, FcERI) or harboured (e.g., Scr tyrosin kinases) [112-115]. Lipid rafts are rich in tyrosine kinase receptors (RTKs), such as EGFR [116-118], IGF1R [119], and HER2 [120]. These receptors have been found to be inhibited by EGCG in several in vitro and in vivo cancer models (e.g., colon, lung, liver and breast cancers) [92,121-123]. The functional proteins recruited by lipid rafts allow these structures to play complex roles. Lipid rafts can float within the plasma membrane or can cluster in larger and stabilized platforms in response to different stimuli. In most cases, the lipid rafts clustering allows for the activation of the proteins [124]. Furthermore, modifications in lipid rafts/protein interaction can lead to alterations in lipid and sterol content, which can, in turn, influence lipid raft functions. Thanks to their capability to interact with several cellular and molecular factors as caveolae [111], viruses [125], bacteria, inflammatory molecules [126,127], and growth factors [128-130], these microdomains are involved in a plethora of biological functions, like cell polarization, membrane trafficking [111], pathogen internalization [126], and regulation of a wide spectrum of signal transduction pathways [131]. Because most of these pathways can control cancer development, progression, rate of cell proliferation [114], migration, invasion [132,133], and apoptosis [134], lipid rafts composition and functions have received much attention. In addition, many anti-cancer agents (e.g., edelfosine, avicin D, resveratrol) exert their anti-tumour activity, at least in part, by altering or disrupting the structure of lipid rafts $[135,136]$.

EGCG has been found to bind to the plasma membrane by interacting with the lipid rafts. The first evidence of this association was shown in the basophilic cell line KU812, where the suppressive action of EGCG on the expression of the high-affinity immunoglobulin E receptor (FceRI) was triggered by direct binding to lipid rafts. This was mediated by the inhibition of Erk1/2 kinases phosphorylation and activation [51]. Shortly after, the same research team observed that the down-regulation of FceRI was driven by EGCG through binding to 67LR, a receptor associated with lipid rafts [110]. Others reported that the EGCG inhibitory effect on EGFR in colon cancer cell line HT29 [92], and on HGFR 
in prostate cancer cell line DU145 [93] was mediated by the alteration of lipid rafts. The collection of signalling pathways affected by lipid rafts structure/function via EGCG/67LR quickly increased in number, as reported in several tumour models, such as multiple myeloma, mammary and epidermiod carcinoma, and chronic myeloid leukemia [52,137-139].

\subsection{Lipid Rafts-Mediated Apoptosis}

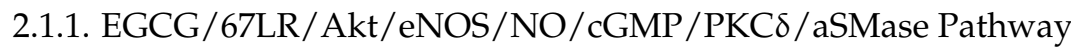

Together with the inhibition of cell proliferation, migration, and angiogenesis, induction of apoptosis is one of the main mechanisms through which EGCG exerts its anti-tumour activity [140,141]. Several studies reported that EGCG is able to affect the expression and function of anti-apoptotic factors (e.g., Bcl-2, Bcl-xl) and to up-regulate pro-apoptotic molecules (e.g., Bax, caspase-3) in several cancer models $[58,142-144]$. However, the mechanisms through which EGCG modulates key cell death regulators are not completely understood. Some studies reported that 67LR plays a relevant role in triggering apoptosis after binding its ligand, EGCG, in haematological malignancies, such as acute myeloid leukemia and multiple myeloma $[145,146]$. More recently, a signalling pathway inducing EGCG/67LR-dependent apoptosis through the activation of protein kinase C $\delta(\mathrm{PKC} \delta)$, acid sphingomyelinase (aSMase), and lipid rafts clustering has been described in multiple myeloma models [137] (Figure 1). The enzyme aSMase is responsible for the catabolism of sphingomyelin (SM) and is known to be part of the signalling cascades that mediates lipid raft-dependent apoptosis [147]. It can be activated in response to external pro-apoptotic stimuli as physical agents (e.g., radiation, UVA light) $[148,149]$, anti-cancer drugs (e.g., cisplantin, doxorubicin) [150,151], and pro-apoptotic receptors (e.g., Fas, TNF-R) $[147,152]$. One of the best described mechanisms of aSMase activation is triggered by Fas receptor. The binding between death receptor Fas, harboured in lipid rafts [153], and its ligand FasL lead to the recruitment of adaptor Fas-associated protein with death domain FADD, which in turn recruits and activates pro-caspase 8 . The final death-inducing signalling complex (DISC) then activates aSMase, which migrates from the cytoplasmic compartment to lipid rafts, where it generates the sphingolipid ceramide from SM [154-156]. In response to ceramide generation, cholesterol is displaced from lipid rafts, thus leading to an increase of membrane fluidity [157]. Ceramide plays a role as second messenger in the signal transduction, inducing lipid raft clustering and the stabilization of DISC complex, amplification of Fas/FasL signalling, finally leading to apoptosis $[155,158,159]$. A similar mechanism has been hypothesized in the case of cervical, prostate and colon cancer, where EGCG administration induces cell apoptosis through aSMase activation and ceramide increase [160-162].

Studies on multiple myeloma cell lines in vitro and in vivo, in patients or murine models, showed that the activation of 67LR through EGCG binding induces the activation of PKC $\delta$ after phosphorylation of Ser664. Activation of PKC $\delta$ leads, in turn, to aSMase activation, and finally to cell apoptosis [137]. These authors pointed out that treatment with $5 \mu \mathrm{M}$ EGCG led to an increase of nitric oxide (NO) [74]. $\mathrm{NO}$ is an inorganic signalling messenger triggering a wide range of cellular pathways. The increase in NO levels is due to the activation of endothelial nitric oxide synthase (eNOS), after phosphorylation in the residue Ser1177 by Akt kinase [74]. Production of NO causes an increase of cGMP, produced by NO-dependent soluble guanylate cyclase (sGC) activation, and then the phosphorylation of PKC $\delta$ [74] (Figure 1). Furthermore, more recently, it has been observed that the anticancer agent coptisine induces apoptosis in hepatocellular carcinoma (HCC) cells via the 67LR/cGMP pathway [163]. Conversely, several studies reported that EGCG negatively regulates eNOS/NO production in different cancer types [75-78] and also sGC/cGMP amount [96].

However, the fact that administration of $5 \mu \mathrm{M}$ EGCG was sufficient to enhance NO production, but not a significant increase of cGMP levels to induce cell apoptosis, gives rise to the question of whether other factors might interfere with cGMP-mediated aSMase activation (Figure 1). Enzyme phosphodiesterase 5 (PDE5), one of the major cGMP negative regulators, was found to be highly expressed in multiple myeloma patients as compared to healthy donors, suggesting that PDE5 could 
be a target for a possible combinatorial therapy with $5 \mu \mathrm{M}$ EGCG [74]. This experimental approach has been implemented. The combined treatment of PDE5 inhibitor Vardenafil and $5 \mu \mathrm{M}$ EGCG caused a strong reduction of cell viability not only in multiple myeloma, but also in other models as prostate, gastric, pancreatic, breast cancer, and in acute myeloid and chronic lymphocytic leukemia cell lines [74,164,165]. Vardenafil and EGCG synergistic action has been found to cause a significant reduction of $\mathrm{IC}_{50}$ of EGCG $[74,164,165]$. The tumour suppressive effects of the combinatorial therapy have also been confirmed in vivo in xenograft murine models of multiple myeloma, treatment that resulted in the reduction of tumour volume and increased survival without hepatotoxicity, a possible side effect of high EGCG administration [74]. In this model, controls (namely cell lines and primary cultures, as well as healthy animal models), were not affected by EGCG alone or in combination with Vardenafil.

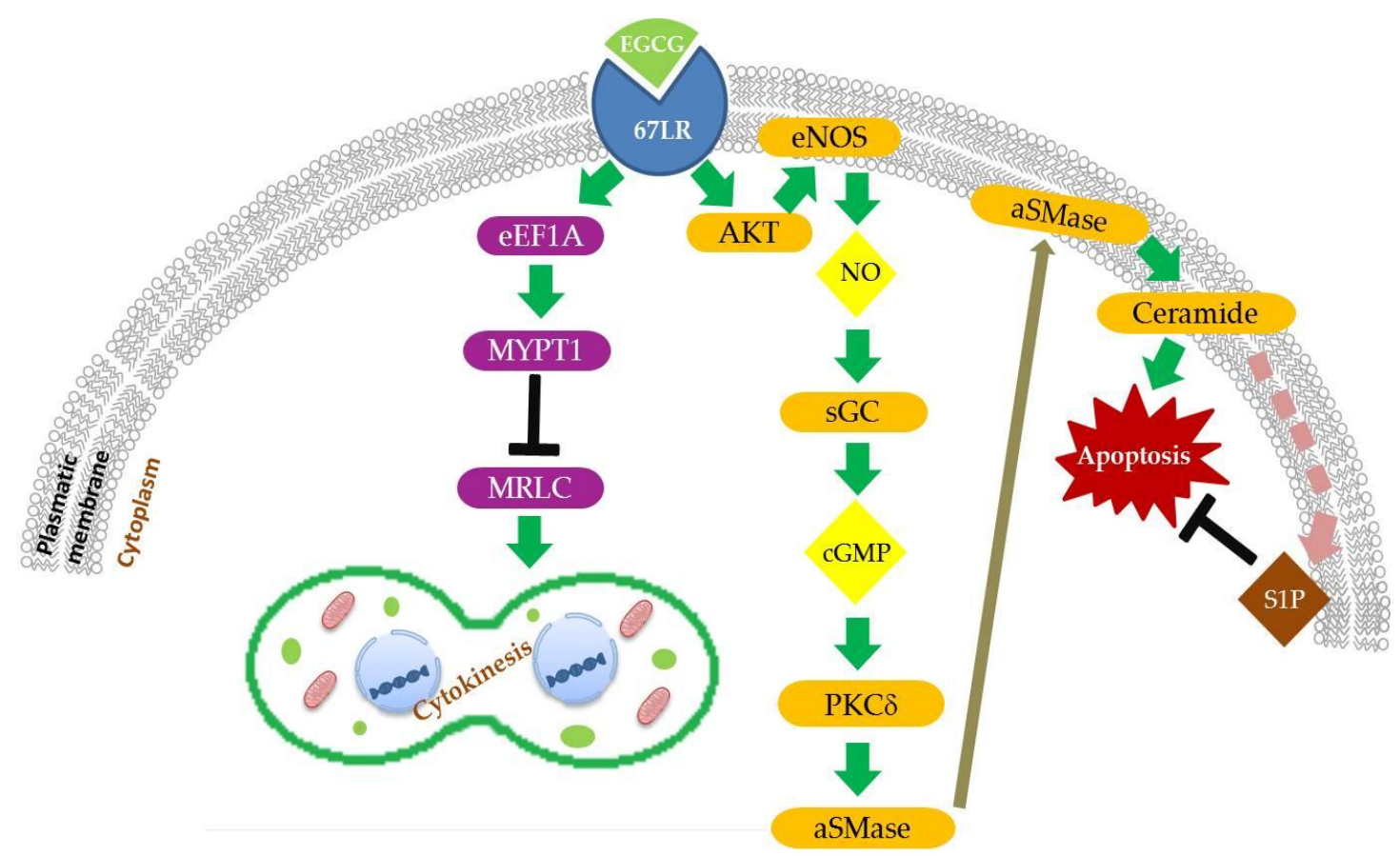

Figure 1. EGCG modulates cell division and apoptosis via 67LR. EGCG binding to 67-kDa laminin receptor (67LR) activates apoptosis program through enhanced nitric oxide (NO) and cGMP production, acid sphingomyelinase ( $\alpha$ SMase) activation and ceramide generation. Ceramide metabolization in sphingosine-1-phosphate (S1P) reduces cell apoptosis. EGCG binding to 67LR inhibits via eukaryotic translation elongation factor 1a (eEF1A) cell cytokinesis inducing myosin phosphatase target subunit (MYPT1) dephosphorylation and activation and myosin II regulatory light chain (MRLC) dephosphorylation and inactivation.

\subsubsection{EGCG/67LR/Ceramide/SphK1/S1P Pathway}

The formation of larger platforms of cholesterol-enriched lipid rafts in cancer cells is often associated with aberrant activation of RTKs, resulting in increased proliferation, survival, and metastatic spread [166]. Instead, ceramide causes cholesterol displacement from lipid rafts, formation of ceramide-enriched lipid rafts, and induction of cell apoptosis [147]. Therefore, ceramide catabolism/degradation may produce anti-apoptotic effects. Ceramide can be deacetylazed and converted to sphingosine, which can be phosphorylated to sphingosine-1-phosphate (S1P) by the sphingosine kinase 1 (SphK1), an enzyme that is highly expressed in several cancers. The S1P can activate protein G-coupled receptors that can in turn activate pro-survival and anti-apoptotic signalling. In prostate cancer models, treatment with high doses of EGCG $(75 \mu \mathrm{M})$ suppressed tumour growth in vitro and in vivo through the inhibition of SphK1/S1P signalling [167] (Figure 1). 
The lesson from these data is that, in a particular cell system, a correct balance between ceramide synthesis and catabolism is fundamental [168,169]. Treatment with $1 \mu \mathrm{M}$ and $5 \mu \mathrm{M}$ EGCG in the multiple myeloma cell line U266 caused the induction of aSMase activity [52]. However, ceramide accumulation has been observed only after giving high concentrations of EGCG (10 $\mu \mathrm{M}$ and $20 \mu \mathrm{M}$ EGCG) [52]. Treatment with these high doses of EGCG leads to the disruption of cholesterol-enriched lipid rafts and the inhibition of phosphorylation and the activation of several RTKs (e.g., EGFR, ErbB2, ErbB3, HGFR, IGF1R, Mer, and Flt3). IGFR inhibition has been demonstrated to be dependent on 67LR and aSMase expression [52]. Because the amount of SphK1 has been found to be increased in multiple myeloma cell lines and specimens from patients, the combinatorial treatment of $5 \mu \mathrm{M}$ EGCG and SphK1 inhibitor Safingol was tested. The data demonstrate that the combination of the two drugs caused an increase in ceramide content, the disruption of cholesterol-enriched lipid rafts, inhibition of RTKs phosphorylation, and finally an increase of cell apoptosis [52]. Furthermore, the combination treatment also affected another cell death mediator that was activated by ceramide, the death-associated protein kinase 1 (DAPK1), causing the de-phosphorylation of DAPK1 inhibitory residue Ser308 and leading to its activation [52].

Thus, like the inhibition of PDE5 with Vardenafil, the simultaneous action on two related pathways employing two agents in combination, produced a synergistic effect that strongly reduced the $\mathrm{IC}_{50}$ of EGCG [52]. The onco-suppressive action of the double treatment (EGCG plus Safingol) has been found effective in vitro in acute myeloid leukemia, chronic myeloid leukemia, and in chronic lymphocytic leukemia models [170]. Absence of toxicity of the combined therapy has also been shown in vivo [52].

\subsection{Cancer Cell Growth Inhibition}

\subsubsection{EGCG/67LR/eEF1a/MYPT1/MRLC Pathway}

EGCG can exert anticancer functions inducing cell cycle arrest. Several studies reported the blockade of the cell division cycle by EGCG administration in G0, G1, S, and G2 phases. EGCG may act through the indirect downregulation of pro-proliferative factors, such as cyclin D1, cyclin E, cyclin A, cyclin $\mathrm{B}, \mathrm{CDK} 4, \mathrm{CDK} 6, \mathrm{CDK} 2$, and CDK1, as well as by the upregulation of anti-proliferative effectors, such as CDK inhibitors p27, p21, p16, and p18 [35,48,56,66,171,172]. In addition, EGCG has been found to act on cytokinesis, a critic step of cell division, by interacting with 67LR receptor $[55,61,173]$.

Cytokinesis is the final step of cell division, leading a mother cell to be divided into two daughter cells. Early events of the process require the formation of an actomyosin ring, also known as contractile ring, that allows the formation of the cleavage furrow at the equator of mitotic cells $[174,175]$. Generation of the furrow enables the equal division of genetic material between the two forming cells and their subsequent separation. The interaction between actin filaments (F-actin) and myosin motors is controlled by different processes among which is the phosphorylation/dephosphorylation of the myosin II regulatory light chain (MRLC). Myosin II is one of the main motors involved in cytokinesis, activated through MRLC phosphorylation at Ser19/Thr18 by kinases, such as MLCK, ROCK, and Citron kinase [176]. Ser19 phosphorylation favours the interaction with F-actin, the contractile ring formation, and filaments assembly. A di-phosphorylation seems to be involved in the assembly of filaments, but the role of phosphorylation in Thr18 alone is less clear [177-179]. Conversely, MRLC dephosphorylation in Ser19 or Ser19/Thr18 by the myosin phosphatase leads to myosin inactivation. The MRLC activity is also indirectly regulated through the phosphorylation of myosin phosphatase itself. When the largest region of myosin phosphatase, called myosin phosphatase target subunit (MYPT1), is phosphorylated in at least one of the inhibitory sites (e.g., Thr696, Thr853), its activity is inhibited, and, as a consequence, MRLC remains active, thus providing a positive signal triggering cytokinesis [180].

EGCG has been found to be able to interfere with the cytokinesis of HeLa cells through its action on MRLC phosphorylation status, thereby affecting the cellular growth [55]. EGCG activates the signalling cascade that is responsible for the impaired MRLC phosphorylation through binding to its membrane 
receptor 67LR [55] (Figure 1). At first, it was reported that the treatment of HeLa cells with 10, 20, and $50 \mu \mathrm{M}$ EGCG resulted in the disruption of stress fibers, reduction of the contractile ring formation, increment of cells blocked in G2/M phases, and inhibition of cell growth [55]. Further analyses revealed that EGCG treatment also caused, via 67LR, a reduction in single Ser19 and in double Ser19/Thr18 MRLC phosphorylation, which effects on MRLC phosphorylation might reasonably trigger the effects shown on cell division and growth [55]. Under similar conditions, EGCG was also found to decrease the phosphorylation of MYTP1 at inhibitory site Thr696 both in vitro and in vivo, thus preventing myosin phosphatase inactivation. According to the literature, the ability of EGCG to interfere with MRLC phosphorylation could be the indirect consequence of MYPT1 loss of inhibition [55]. Recently, another factor has been added to the members of the EGCG signalling pathway, believed to be responsible for impaired cancer cell cytokinesis: the eukaryotic translation elongation factor 1a (eEF1a), which has been found to be necessary to enable EGCG to alter MYPT1 phosphorylation status [61]. eEF1a is mainly known as a component of the eukaryotic translation machinery, but it also takes part in other cellular processes, such as senescence, oncogenic transformation, and cell proliferation [181-183]. eEF1a is able to bind to MYPT1 and F-actin [184]. In vitro and in vivo experiments demonstrated that no significant reduction in MYPT1 and MRLC phosphorylation, actin disassembly and cell proliferation was observed after EGCG administration in eEF1a knockout models [61]. This evidence has been further corroborated by the observation that when eEF1a levels are restored and 67LR is absent, the effects that are described above disappear as well. Thereby, eEF1a is thought to be downstream of 67LR and upstream of MYPT1 in the signalling pathway that is triggered by EGCG [61] (Figure 1).

\subsubsection{EGCG/67LR/cAMP/PKA/PP2A Pathway}

67LR surface receptor is involved in the selective anti-tumour activity exerted by EGCG in melanomas. Tsukamoto et al. identified protein phosphatase 2A (PP2A) as a downstream target of 67LR in melanoma cells [86]. PP2A is a Ser/Thr phosphatase that is involved in important cellular processes, such as proliferation, signal transduction, and apoptosis, and it is considered to be a tumor suppressor that is functionally inactivated in cancer $[185,186]$.

By performing functional genetic screening, Tsukamoto and colleagues showed that EGCG binding to 67LR receptor induces PP2A activation mediated by the cAMP/PKA pathway [86], which led to the suppression of melanoma tumor cell growth. Even though the direct interaction between EGCG and PP2A was demonstrated using very high EGCG concentrations [84,187,188], $1 \mu \mathrm{M}$ EGCG was sufficient to activate 67LR/PP2A pathway. PP2A directly interacts with p70S6k and down-regulates mTOR signaling [189], which is usually aberrantly activated in melanomas. Therefore, it represents an important contribution to chemotherapeutic resistance of commonly used BRAF inhibitor treatment. The EGCG-activating 67LR/PP2A pathway exerts a strong synergistic effect with PLX4720, a BRAF inhibitor, in drug-resistant melanomas.

Another effect that is mediated by the 67LR/PP2A signaling is the activation of Merlin, a tumor suppressor protein that is encoded by the NF2 gene at physiological concentrations of EGCG, as low as $1 \mu \mathrm{M}$ [86]. Merlin activity seems to target cell surface RTKs and adhesion/extracellular matrix receptors, regulating cell proliferation, survival and motility [190]. PKA, p21-activated kinase 1 and 2 (PAK 1/2), or MYPT can activate Merlin by dephosphorylation at Ser-518. In the study by Tsukamoto et al. [86], EGCG was demonstrated to be an activator of Merlin via 67LR/PP2A pathway. In prostate cancer cell lines the absence or inactivation of Merlin contributes to tumor development and progression toward a highly invasive and chemo-resistant state [191-193].

Recently published data show that $10 \mu \mathrm{M}$ EGCG up-regulates let-7b miRNA expression not only in melanoma cell lines, but also in metastatic melanoma tumours in vivo [81]. miRNAs are non-coding RNAs transcripts that are able to regulate fundamental biological activities related to mRNA degradation or translational inhibition [194]. Yamada et al. demonstrated that 67LR is involved in the EGCG-elicited let-7b increase, which leads to the inhibition of melanoma tumor progression [81]. 
Let- $7 \mathrm{~b}$ recognizes multiple target genes that are related to tumor progression, such as the high mobility group A2 (HMGA2), decreased in EGCG-treated melanoma cells [81], or Ras [195,196].

Furthermore, the data indicated that PP2A inactivation caused the induction of let-7b, which is generally down-regulated in cancer (including melanoma and prostate cancer) [81,197], even if it is not clear whether let-7b transcription or let-7b processing is modulated by EGCG-induced PP2A activation.

Zhou et al. confirmed that EGCG induced miRNAs profile changes in a mouse model of lung tumor. They highlighted that the miRNAs affected by EGCG and target genes are different from those that were previously identified by in vivo studies [198].

\subsection{Modulation of Cancer Stem Cells Properties}

EGCG was shown to affect the survival of cancer stem cells (CSCs). EGCG inhibits CSCs growth and stemness in several malignancies, such as breast [199], lung [54,200], colorectal cancer [85], osteosarcoma [14], and neuroblastoma [201].

Kumazoe M. et al. [202] describe the effects of EGCG on the features of pancreatic CSCs (i.e., the capability to form colonies and spheroids) through the activation of the EGCG/67LR/cGMP axis. The same research team had observed that spheroid formation in pancreatic CSCs colonies was inhibited by cGMP targeting of the Forkhead box O3 (FOXO3)/CD44 axes [203]. Transcriptional factor FOXO3 is known to be a cancer suppressor, but it also induces the high expression of CD44, a master regulator (and also a marker) of CSCs [202]. FOXO3 has been shown to be a direct target of EGCG in tumours, like pancreatic and breast cancer. In pancreatic cancer treatment with EGCG suppressed tumour growth, accompanied by FOXO3 downregulation [99]. By contrast, in breast cancer, a positive regulation of FOXO3 exerted by the EGCG has been described $[70,204,205]$. Although the reported modulations seem to be opposite, the action of EGCG on FOXO3 seems to lead to cancer suppression altogether. Recently, the role of EGCG in inhibiting cancer stem cells (CSC) growth and altering their features is emerging $[54,95,199]$. According to this literature, EGCG seems to act by downregulating CD44 expression in tumours, like non-small cell lung cancer and pancreatic cancer [200,202]. In pancreatic cancer cell lines expressing CD44, the isoform 3A of the enzyme phosphodiesterase (PDE3A) is highly expressed [202]. Like other members of the same family, PDE3A is a negative regulator of cGMP [206]. In pancreatic cancer cells, low EGCG administration did not lead to a significant increase in cGMP amount, or to the reduction of colony and spheroid formation [202]. Further experiments were conducted using low doses of EGCG combined with the administration of a PDE3A inhibitor, Trequinsin. The combination therapy decreased the protein levels of FOXO3 and CD44, caused an increase of CGMP, and a strong reduction in the CSCs capability to form both colonies and spheroids. The combination of EGCG and Trequinsin is synergistic and it reduces the $\mathrm{IC}_{50}$ of EGCG, thus allowing for its use at physiological concentration. These observations have also been confirmed in vivo [202]. Surprisingly, as for the other signalling pathway that is discussed above, the effects of EGCG alone, or in combination with other agents, are always specific for cancer cells, and they do not affect normal cells. This highly specific effect of EGCG is still waiting for an explanation.

\section{Other EGCG-Interacting Proteins}

Another interesting protein that was shown to interact directly with green tea catechins is the human peptidyl prolyl cis/trans isomerase (Pin1). Pin is a protein with two domains: an N-terminal WW-domain and a C-terminal PPIase domain; both are necessary for its function. Although many PPIases have been identified some with an established role in cancer, only Pin1 acts distinctively and specifically on phosphorylated proteins. Pin1 catalyzes the cis/trans isomerization of the peptidyl proline bond of proteins. This activity causes major changes in the conformation of the target protein, with a consequent alteration of its function or stability. In this way, Pin1 affects and modulatse different pathways involving kinase-dependent signaling, such as NF-kB, activator-protein 1 (AP-1), nuclear factor of activated T cells (NFAT), or b-catenin [207]. Pin1 has been demonstrated to have a major 
role in oncogenic signaling [208,209] and is highly expressed in several cancers [210,211], including prostate cancer [212].

Urusova et al. used crystallographic and biochemical data to show that EGCG interacts directly with both the PPase and WW domains of Pin1, which inhibits its tumour-promoting activity. Therefore, Pin1 represent a possible target for anti-cancer therapies $[83,213]$. The dissociation constant of EGCG and Pin 1 has been calculated as $21 \mu \mathrm{M}$, both by protease-coupled and isothermal titration calorimetric assays: this value is similar to the concentration of EGCG that was found to exert anti-cancer effects in experimental cancer models [40]. Since the Kd value that resulted was quite high, the interaction between EGCG and Pin1 was described as "not strong". Urusova and colleagues crystallized the Pin1-EGCG complex, resolving its structure at $1.9 \AA$ resolution by X-ray diffraction. The crystal structure has revealed that a molecule of EGCG was bound to Pin1 WW domain (aminoacids 1-31), which is responsible for the interaction with the substrate, while another molecule of EGCG was bound to the Pin1 PPIase domain, necessary for the isomerization reaction. A recent study demonstrated that galloyl group in EGCG is required for Pin1 inhibition [214]. Binding between EGCG and Pin1 in solution has been studied recently by combining fluorescence spectrum, far-UV circular dichroism spectrum with molecular dynamics simulations. The analysis of the binding energy confirmed the strong inhibitory effect that is exerted by EGCG on Pin1 activity [215].

To analyze the functional consequence of Pin1-EGCG binding, Urusova and colleagues used mouse embryonal fibroblasts (MEF) collected from PIN1 KO and WT mice, and showed that Pin1 expression is required for EGCG $(10-40 \mu \mathrm{M})$ inhibitory effect on MEFs growth. Furthermore, the formation of the EGCG-Pin1 complex prevented the binding of the Pin1 substrate c-Jun. Finally, EGCG effect on transcriptional regulation of AP-1 and NF-kB has been shown to be mediated by Pin1 [83].

Green tea catechins are mainly believed to prevent cancer. However, several epidemiological studies suggest that their activity also works against cancer progression; the interaction of EGCG with proteins that are involved in cancer progression and metastatic spread has been considered. One of the effects exerted by EGCG is the inhibition of TGF- $\beta$ signaling transduction. TGF- $\beta$ is a multifunctional cytokine that induces epithelial-mesenchymal transition (EMT) of cancer cells, and it is also responsible for the maintenance of EMT, a critical event during early metastatic growth. The mechanism by which EGCG modulates TGF- $\beta$ pathway has not been completely elucidated. It has been shown that the binding between TGF- $\beta$ and its receptor, TGFR-II, activates two different pathways leading to EMT: the canonical Smad-dependent pathway and the mitogen-activated protein kinase (MAPK) pathway. Tabuchi et al. used immunoprecipitation and affinity chromatography assays to demonstrate binding between EGCG and TGFR-II protein. This interaction may be responsible for the inhibitory effect of EGCG on the expression of alpha-SMA (considered a marker of the EMT) via the TGF-beta Smad2/3 pathway in human lung fibroblast cells [94].

EGCG has also been shown to bind to metalloproteinases (MMPs). MMPs are matrix degrading enzymes that are involved in tumor invasion and metastasis [50] whose expression is regulated by several growth factors, including TGF- $\beta 1$ [216-219]. Sazuka et al. have demonstrated that EGCG inhibits the collagenase activity of MMP- 2 and MMP-9 produced by lung carcinoma cells. The authors suggest that the mechanism of inhibition relies on direct binding between EGCG and MMP proteins, as proved by affinity gel chromatography experiments [50]. In 2017, Chowdhury et al. performed a preliminary in silico analysis and then showed a strong interaction of pro-/active MMP2 with the galloyl group of EGCG and ECG in pulmonary artery smooth muscle cell culture supernatant. They showed that EGCG and ECG were better inhibitors of proMMP2 when compared to MMP2, and they demonstrated that a strong interaction with MT1/MMP is involved in the conversion of proMMP2 to active MMP2 [220]. Further, investigating the interactions of pro-/active MMP-9 with green tea catechins by computational methods, they showed strong interactions between pro-/active MMP9 and EGCG/ECG [221]. 


\section{EGCG Epigenetic Regulation}

Another mechanism that can explain the pleiotropic effects exerted by green tea catechins in tumor cells is the epigenetic change in gene expression and chromatin organization. Mutations in oncogenes and tumor suppressor genes are often the cause of cancer development and alterations of gene expression count for cancer progression.

Many biologically active compounds, including EGCG, have been demonstrated to modulate DNA methylation and histone acetylation status [222].

DNA methyltransferases (DNMTs) and histone deacetylases (HDACs) are enzymes that are involved in transcriptional gene silencing and histone acetyl transferases (HATs) positively regulate gene expression regulation [223,224]. Several studies reported EGCG contribution in epigenetic control acting on DNMTs, HDACs and HATs expression and activity in different tumours. We will briefly mention different genes whose expression is enhanced or reduced by EGCG-dependent epigenetic control.

Fang et al. demonstrated that EGCG binds to DNMT and competitively inhibits the enzymatic activity (Ki of $6.89 \mu \mathrm{M}$ ), yielding the reactivation of methylation-silenced genes in prostate cancer PC3 cells [225]. Molecular modeling and docking studies supported the binding of EGCG to DNMT3B and HDAC1 [39].

In HeLa cell line, it has been observed that EGCG can direct bind to and inhibit DNMT1, DNMT3B, and HDAC1 activity, causing a reduction in DNA hypermethylation and restoring the expression of repressed genes as retinoic acid receptor $\beta(R A R \beta), C D H 1$ (e-cadherine gene), and DAPK1 [29,39]. Furthermore, in the same the same cell line, EGCG combination with eugenol-amrogentin (active compounds of clove and Swertia Chirata, respectively) reduces DNMT1 expression with the consequent hypomethylation of the cell cycle inhibitors $\mathrm{p} 16$ and LimD1 promoters [226]. In acute promyelocytic leukemia cells, EGCG down-regulates DNMT1, HDAC1, HDAC2, G9a, and Polycomb repressive complex 2 (PRC2) core components expression and favours the binding of hyperacetylated $\mathrm{H} 4$ and acetylated $\mathrm{H} 3 \mathrm{~K} 14$ histones to promoter regions of $\mathrm{p} 27, \mathrm{CAF}, \mathrm{C} / \mathrm{EBP} \alpha$, and $\mathrm{C} / \mathrm{EBP} \varepsilon$ genes [63]. In the lung cell line PC-9, EGCG combination with Am80 (a synthetic retinoid used for acute promyelocytic leukemia therapy) causes a decrease of HDAC4, HDAC5, and HDAC6 protein levels and reduction of HDAC activity, leading to increased p53 and $\alpha$-tubulin acetylation [227]. In in vitro and in vivo models of lung cancer, EGCG has been found to resensitize tumor cells to Cisplatin (DDP)-based combination chemotherapy through DNMT and HDAC activity inhibition, and the subsequent re-expression of GAS1, TIMP4, ICAM1, and WISP2 genes [228]. In in vivo model of lung cancer, EGCG epigenetic action in down-regulating DNMT1 is accompanied by phospho-histone H2AX $(\gamma-\mathrm{H} 2 \mathrm{AX})$ and p-AKT reduction [229]. In skin cancer cells, it has demonstrated EGCG capability in reducing DNMT1, DNMT3A, and DNMT3B activity and expression, and also in increasing histones $\mathrm{H} 3$ and $\mathrm{H} 4$ acetylation. As a consequence of the described epigenetic changes, a restored expression of the cell cycle inhibitors p16 and p21 has been observed [48]. In breast cancer cells, EGCG-dependent reduction of HDAC1 and zeste homolog 2 (EZH2) protein levels leads to tissue inhibitor of matrix metalloproteinase-3 (TIMP-3) gene transcriptional activation [72]. In prostate cancer cell lines, it has been observed that the EGCG-dependent reduction of the acetylated androgen receptor (AR) gene might be induced by EGCG reduction in HAT activity [65]. EGCG also acts on teleomerase, reducing its activity in different tumor types as esophageal carcinoma [230], glioma [231], cervical cancer [232], breast cancer [100], nasopharyngeal carcinoma [233], ovarian cancer [68], laryngeal squamous cell carcinoma [234], and lung cancer [235]. It has also been shown that EGCG can translocate from the cytoplasm to the nucleus where it can bind to DNA, suggesting a possible role in gene expression regulation also through the direct binding to nucleic acid $[236,237]$. However, the effects of EGCG/DNA direct interaction need to be clarified. 


\section{Conclusions}

Because of their anti-proliferative, pro-apoptotic, and anti-oxidative properties, green tea catechins and especially EGCG are receiving much attention in cancer biology. Several in vitro, in vivo, and clinical studies, have demonstrated that EGCG exerts anti-cancer effects in different models through the activation/inhibition of several signalling pathways, most of which are triggered by the direct interaction between EGCG and specific protein targets. The array of EGCG interactors is wide and growing, and it includes intracellular molecules, membranes receptors, membrane microdomains, and the plasma membrane itself. One of the first EGCG direct target identified was 67LR, but in recent years, others interactors, such as Pin1 or TGFR-II, have been recognized. Appropriate identification and study of EGCG direct targets will allow a better understanding of its mechanisms of action and a better exploitation of its anti-cancer properties. From 2004, when the 67LR was first identified as direct target of EGCG by Tachibana et al., several research teams have investigated the pathways modulated by EGCG-67LR interaction. Today, we know that the anti-proliferative action of EGCG is mediated by the binding to 67LR, whose expression is increased in tumour cells. Convincing experimental data also showed that membrane composition is involved in the inhibitory activity of EGCG in some cancer cells lines. Since 67LR is generally located in lipid rafts, EGCG-mediated microdomains composition and the alteration of their functions triggers the downstream signalling cascades. In addition, new experimental data have brought to light novel EGCG signalling cascades leading to cell apoptosis, cell cycle arrest, reduction in CSC colony and spheroid formation, as well as regulation of miRNAs expression. EGCG binding to membrane receptors, such as TGFR-II, intracellular molecules, such as Pin1 and secreted enzymes, such as MMPs, provided noteworthy information about the mechanisms of EGCG-mediated tumour suppression. Another mechanism to explain the pleiotropic anti-cancer effects that are exerted by EGCG and green tea catechins that is gaining the attention of the researchers is the modulation of epigenetic processes. Long-term administration of green tea catechins leads to the re-activation of tumour suppressor genes that are silenced during carcinogenesis and downregulation of oncogenes through the inhibition of enzymes, such as DNMTs and HDACs involved in DNA methylation and chromatin remodelling. Further studies on the interaction of EGCG with protein targets will provide new insights enabling the development of more pharmacological treatments targeting EGCG-activated master regulators of key pathways.

Author Contributions: A.N., V.N., F.R. and S.B. critically reviewed the literature and wrote the manuscript.

Funding: This research received no external funding.

Acknowledgments: V.N. was supported by a fellowship by Fondazione Umberto Veronesi. We thank Paul Wegener for English editing support.

Conflicts of Interest: The authors declare no conflict of interest.

\section{References}

1. Graham, H.N. Green tea composition, consumption, and polyphenol chemistry. Prev. Med. 1992, 21, 334-350. [CrossRef]

2. Lowe, G.M.; Gana, K.; Rahman, K. Dietary supplementation with green tea extract promotes enhanced human leukocyte activity. J. Complement. Integr. Med. 2015, 12, 277-282. [CrossRef] [PubMed]

3. Boschmann, M.; Thielecke, F. The effects of epigallocatechin-3-gallate on thermogenesis and fat oxidation in obese men: A pilot study. J. Am. Coll. Nutr. 2007, 26, 389S-395S. [CrossRef] [PubMed]

4. Basu, A.; Sanchez, K.; Leyva, M.J.; Wu, M.; Betts, N.M.; Aston, C.E.; Lyons, T.J. Green tea supplementation affects body weight, lipids, and lipid peroxidation in obese subjects with metabolic syndrome. J. Am. Coll. Nutr. 2010, 29, 31-40. [CrossRef] [PubMed]

5. Ide, K.; Yamada, H.; Takuma, N.; Park, M.; Wakamiya, N.; Nakase, J.; Ukawa, Y.; Sagesaka, Y.M. Green tea consumption affects cognitive dysfunction in the elderly: A pilot study. Nutrients 2014, 6, 4032-4042. [CrossRef] [PubMed] 
6. Bettuzzi, S.; Brausi, M.; Rizzi, F.; Castagnetti, G.; Peracchia, G.; Corti, A. Chemoprevention of human prostate cancer by oral administration of green tea catechins in volunteers with high-grade prostate intraepithelial neoplasia: A preliminary report from a one-year proof-of-principle study. Cancer Res. 2006, 66, 1234-1240. [CrossRef]

7. Khan, N.; Afaq, F.; Saleem, M.; Ahmad, N.; Mukhtar, H. Targeting multiple signaling pathways by green tea polyphenol (-)-epigallocatechin-3-gallate. Cancer Res. 2006, 66, 2500-2505. [CrossRef]

8. Yang, C.S.; Sang, S.; Lambert, J.D.; Lee, M.J. Bioavailability issues in studying the health effects of plant polyphenolic compounds. Mol. Nutr. Food Res. 2008, 52 (Suppl. 1), S139-S151. [CrossRef]

9. Lee, M.J.; Wang, Z.Y.; Li, H.; Chen, L.; Sun, Y.; Gobbo, S.; Balentine, D.A.; Yang, C.S. Analysis of plasma and urinary tea polyphenols in human subjects. Cancer Epidemiol. Biomarkers Prev. 1995, 4, 393-399.

10. Gan, R.Y.; Li, H.B.; Sui, Z.Q.; Corke, H. Absorption, metabolism, anti-cancer effect and molecular targets of epigallocatechin gallate (egcg): An updated review. Crit. Rev. Food Sci. Nutr. 2018, 58, 924-941. [CrossRef]

11. Zubair, H.; Azim, S.; Ahmad, A.; Khan, M.A.; Patel, G.K.; Singh, S.; Singh, A.P. Cancer chemoprevention by phytochemicals: Nature's healing touch. Molecules 2017, 22, 395. [CrossRef] [PubMed]

12. Jin, G.; Yang, Y.; Liu, K.; Zhao, J.; Chen, X.; Liu, H.; Bai, R.; Li, X.; Jiang, Y.; Zhang, X.; et al. Combination curcumin and (-)-epigallocatechin-3-gallate inhibits colorectal carcinoma microenvironment-induced angiogenesis by jak/stat3/il-8 pathway. Oncogenesis 2017, 6, e384. [PubMed]

13. Chan, M.M.; Chen, R.; Fong, D. Targeting cancer stem cells with dietary phytochemical—Repositioned drug combinations. Cancer Lett. 2018, 433, 53-64. [CrossRef] [PubMed]

14. Wang, W.; Chen, D.; Zhu, K. Sox2ot variant 7 contributes to the synergistic interaction between egcg and doxorubicin to kill osteosarcoma via autophagy and stemness inhibition. J. Exp. Clin. Cancer Res. 2018, 37, 37. [CrossRef] [PubMed]

15. Mayr, C.; Wagner, A.; Neureiter, D.; Pichler, M.; Jakab, M.; Illig, R.; Berr, F.; Kiesslich, T. The green tea catechin epigallocatechin gallate induces cell cycle arrest and shows potential synergism with cisplatin in biliary tract cancer cells. BMC Complement. Altern. Med. 2015, 15, 194. [CrossRef]

16. Zhou, Y.; Tang, J.; Du, Y.; Ding, J.; Liu, J.Y. The green tea polyphenol egcg potentiates the antiproliferative activity of sunitinib in human cancer cells. Tumour. Biol. 2016, 37, 8555-8566. [CrossRef]

17. Yuan, X.; He, Y.; Zhou, G.; Li, X.; Feng, A.; Zheng, W. Target challenging-cancer drug delivery to gastric cancer tissues with a fucose graft epigallocatechin-3-gallate-gold particles nanocomposite approach. J. Photochem. Photobiol. B 2018, 183, 147-153. [CrossRef]

18. Hajipour, H.; Hamishehkar, H.; Nazari Soltan Ahmad, S.; Barghi, S.; Maroufi, N.F.; Taheri, R.A. Improved anticancer effects of epigallocatechin gallate using rgd-containing nanostructured lipid carriers. Artif. Cells Nanomed. Biotechnol. 2018. [CrossRef]

19. Sanna, V.; Singh, C.K.; Jashari, R.; Adhami, V.M.; Chamcheu, J.C.; Rady, I.; Sechi, M.; Mukhtar, H.; Siddiqui, I.A. Targeted nanoparticles encapsulating (-)-epigallocatechin-3-gallate for prostate cancer prevention and therapy. Sci. Rep. 2017, 7, 41573. [CrossRef]

20. Krupkova, O.; Ferguson, S.J.; Wuertz-Kozak, K. Stability of (-)-epigallocatechin gallate and its activity in liquid formulations and delivery systems. J. Nutr. Biochem. 2016, 37, 1-12. [CrossRef]

21. Rizzi, F.; Naponelli, V.; Silva, A.; Modernelli, A.; Ramazzina, I.; Bonacini, M.; Tardito, S.; Gatti, R.; Uggeri, J.; Bettuzzi, S. Polyphenon e(r), a standardized green tea extract, induces endoplasmic reticulum stress, leading to death of immortalized pnt1a cells by anoikis and tumorigenic pc3 by necroptosis. Carcinogenesis 2014, 35, 828-839. [CrossRef] [PubMed]

22. Modernelli, A.; Naponelli, V.; Giovanna Troglio, M.; Bonacini, M.; Ramazzina, I.; Bettuzzi, S.; Rizzi, F. Egcg antagonizes bortezomib cytotoxicity in prostate cancer cells by an autophagic mechanism. Sci. Rep. 2015, 5, 15270. [CrossRef] [PubMed]

23. Thawonsuwan, J.; Kiron, V.; Satoh, S.; Panigrahi, A.; Verlhac, V. Epigallocatechin-3-gallate (egcg) affects the antioxidant and immune defense of the rainbow trout, oncorhynchus mykiss. Fish. Physiol. Biochem. 2010, 36, 687-697. [CrossRef] [PubMed]

24. Lambert, J.D.; Elias, R.J. The antioxidant and pro-oxidant activities of green tea polyphenols: A role in cancer prevention. Arch. Biochem. Biophys. 2010, 501, 65-72. [CrossRef] [PubMed]

25. Gupta, S.; Hastak, K.; Afaq, F.; Ahmad, N.; Mukhtar, H. Essential role of caspases in epigallocatechin3-gallate-mediated inhibition of nuclear factor kappa b and induction of apoptosis. Oncogene 2004, 23, 2507-2522. [CrossRef] [PubMed] 
26. Shimizu, M.; Adachi, S.; Masuda, M.; Kozawa, O.; Moriwaki, H. Cancer chemoprevention with green tea catechins by targeting receptor tyrosine kinases. Mol. Nutr. Food Res. 2011, 55, 832-843. [CrossRef]

27. Singh, B.N.; Shankar, S.; Srivastava, R.K. Green tea catechin, epigallocatechin-3-gallate (egcg): Mechanisms, perspectives and clinical applications. Biochem. Pharmacol. 2011, 82, 1807-1821. [CrossRef]

28. Lin, C.H.; Shen, Y.A.; Hung, P.H.; Yu, Y.B.; Chen, Y.J. Epigallocathechin gallate, polyphenol present in green tea, inhibits stem-like characteristics and epithelial-mesenchymal transition in nasopharyngeal cancer cell lines. BMC Complement. Altern. Med. 2012, 12, 201. [CrossRef] [PubMed]

29. Lee, W.J.; Shim, J.Y.; Zhu, B.T. Mechanisms for the inhibition of DNA methyltransferases by tea catechins and bioflavonoids. Mol. Pharmacol. 2005, 68, 1018-1030. [CrossRef]

30. Shirakami, Y.; Shimizu, M. Possible mechanisms of green tea and its constituents against cancer. Molecules 2018, 23, 2284. [CrossRef]

31. Rahmani, A.H.; Al Shabrmi, F.M.; Allemailem, K.S.; Aly, S.M.; Khan, M.A. Implications of green tea and its constituents in the prevention of cancer via the modulation of cell signalling pathway. BioMed Res. Int. 2015, 2015, 925640. [CrossRef] [PubMed]

32. Naponelli, V.; Ramazzina, I.; Lenzi, C.; Bettuzzi, S.; Rizzi, F. Green tea catechins for prostate cancer prevention: Present achievements and future challenges. Antioxidants 2017, 6, 26. [CrossRef] [PubMed]

33. Ellinger, S.; Muller, N.; Stehle, P.; Ulrich-Merzenich, G. Consumption of green tea or green tea products: Is there an evidence for antioxidant effects from controlled interventional studies? Phytomedicine 2011, 18, 903-915. [CrossRef] [PubMed]

34. Shankar, S.; Ganapathy, S.; Hingorani, S.R.; Srivastava, R.K. Egcg inhibits growth, invasion, angiogenesis and metastasis of pancreatic cancer. Front. Biosci. 2008, 13, 440-452. [CrossRef] [PubMed]

35. Gupta, S.; Hussain, T.; Mukhtar, H. Molecular pathway for (-)-epigallocatechin-3-gallate-induced cell cycle arrest and apoptosis of human prostate carcinoma cells. Arch. Biochem. Biophys. 2003, 410, 177-185. [CrossRef]

36. Shimizu, M.; Shirakami, Y.; Moriwaki, H. Targeting receptor tyrosine kinases for chemoprevention by green tea catechin, egcg. Int. J. Mol. Sci. 2008, 9, 1034-1049. [CrossRef]

37. Shimizu, M.; Weinstein, I.B. Modulation of signal transduction by tea catechins and related phytochemicals. Mutat. Res. 2005, 591, 147-160. [CrossRef] [PubMed]

38. Pandey, M.; Shukla, S.; Gupta, S. Promoter demethylation and chromatin remodeling by green tea polyphenols leads to re-expression of gstp1 in human prostate cancer cells. Int. J. Cancer 2010, 126, 2520-2533. [CrossRef] [PubMed]

39. Khan, M.A.; Hussain, A.; Sundaram, M.K.; Alalami, U.; Gunasekera, D.; Ramesh, L.; Hamza, A.; Quraishi, U. (-)-epigallocatechin-3-gallate reverses the expression of various tumor-suppressor genes by inhibiting DNA methyltransferases and histone deacetylases in human cervical cancer cells. Oncol. Rep. 2015, 33, 1976-1984. [CrossRef] [PubMed]

40. Rouzer, C.A.; Marnett, L.J. Green tea gets molecular. Cancer Prev. Res. 2011, 4, 1343-1345. [CrossRef]

41. Saeki, K.; Hayakawa, S.; Nakano, S.; Ito, S.; Oishi, Y.; Suzuki, Y.; Isemura, M. In vitro and in silico studies of the molecular interactions of epigallocatechin-3-o-gallate (egcg) with proteins that explain the health benefits of green tea. Molecules 2018, 23, 1295. [CrossRef] [PubMed]

42. Ermakova, S.; Choi, B.Y.; Choi, H.S.; Kang, B.S.; Bode, A.M.; Dong, Z. The intermediate filament protein vimentin is a new target for epigallocatechin gallate. J. Biol. Chem. 2005, 280, 16882-16890. [CrossRef]

43. He, Z.; Tang, F.; Ermakova, S.; Li, M.; Zhao, Q.; Cho, Y.Y.; Ma, W.Y.; Choi, H.S.; Bode, A.M.; Yang, C.S.; et al. Fyn is a novel target of (-)-epigallocatechin gallate in the inhibition of jb6 cl41 cell transformation. Mol. Carcinog. 2008, 47, 172-183. [CrossRef] [PubMed]

44. Shim, J.H.; Choi, H.S.; Pugliese, A.; Lee, S.Y.; Chae, J.I.; Choi, B.Y.; Bode, A.M.; Dong, Z. (-)-epigallocatechin gallate regulates $\mathrm{cd} 3$-mediated $\mathrm{t}$ cell receptor signaling in leukemia through the inhibition of zap-70 kinase. J. Biol. Chem. 2008, 283, 28370-28379. [CrossRef] [PubMed]

45. Li, M.; He, Z.; Ermakova, S.; Zheng, D.; Tang, F.; Cho, Y.Y.; Zhu, F.; Ma, W.Y.; Sham, Y.; Rogozin, E.A.; et al. Direct inhibition of insulin-like growth factor-i receptor kinase activity by (-)-epigallocatechin-3-gallate regulates cell transformation. Cancer Epidemiol. Biomarkers Prev. 2007, 16, 598-605. [CrossRef] [PubMed]

46. Ermakova, S.P.; Kang, B.S.; Choi, B.Y.; Choi, H.S.; Schuster, T.F.; Ma, W.Y.; Bode, A.M.; Dong, Z. (-)-epigallocatechin gallate overcomes resistance to etoposide-induced cell death by targeting the molecular chaperone glucose-regulated protein 78. Cancer Res. 2006, 66, 9260-9269. [CrossRef] [PubMed] 
47. Fujimura, Y. Small molecule-sensing strategy and techniques for understanding the functionality of green tea. Biosci. Biotechnol. Biochem. 2015, 79, 687-699. [CrossRef]

48. Nandakumar, V.; Vaid, M.; Katiyar, S.K. (-)-epigallocatechin-3-gallate reactivates silenced tumor suppressor genes, cip1/p21 and p16ink4a, by reducing DNA methylation and increasing histones acetylation in human skin cancer cells. Carcinogenesis 2011, 32, 537-544. [CrossRef]

49. Hu, Q.; Chang, X.; Yan, R.; Rong, C.; Yang, C.; Cheng, S.; Gu, X.; Yao, H.; Hou, X.; Mo, Y.; et al. (-)-epigallocatechin-3-gallate induces cancer cell apoptosis via acetylation of amyloid precursor protein. Med. Oncol. 2015, 32, 390. [CrossRef]

50. Sazuka, M.; Imazawa, H.; Shoji, Y.; Mita, T.; Hara, Y.; Isemura, M. Inhibition of collagenases from mouse lung carcinoma cells by green tea catechins and black tea theaflavins. Biosci. Biotechnol. Biochem. 1997, 61, 1504-1506. [CrossRef]

51. Fujimura, Y.; Tachibana, H.; Yamada, K. Lipid raft-associated catechin suppresses the fcepsilonri expression by inhibiting phosphorylation of the extracellular signal-regulated kinase1/2. FEBS Lett. 2004, 556, $204-210$. [CrossRef]

52. Tsukamoto, S.; Huang, Y.; Kumazoe, M.; Lesnick, C.; Yamada, S.; Ueda, N.; Suzuki, T.; Yamashita, S.; Kim, Y.H.; Fujimura, Y.; et al. Sphingosine kinase-1 protects multiple myeloma from apoptosis driven by cancer-specific inhibition of rtks. Mol. Cancer Ther. 2015, 14, 2303-2312. [CrossRef] [PubMed]

53. Wu, P.P.; Kuo, S.C.; Huang, W.W.; Yang, J.S.; Lai, K.C.; Chen, H.J.; Lin, K.L.; Chiu, Y.J.; Huang, L.J.; Chung, J.G. (-)-epigallocatechin gallate induced apoptosis in human adrenal cancer nci-h295 cells through caspase-dependent and caspase-independent pathway. Anticancer Res. 2009, 29, 1435-1442. [PubMed]

54. Zhu, J.; Jiang, Y.; Yang, X.; Wang, S.; Xie, C.; Li, X.; Li, Y.; Chen, Y.; Wang, X.; Meng, Y.; et al. Wnt/beta-catenin pathway mediates (-)-epigallocatechin-3-gallate (egcg) inhibition of lung cancer stem cells. Biochem. Biophys. Res. Commun. 2017, 482, 15-21. [CrossRef] [PubMed]

55. Umeda, D.; Tachibana, H.; Yamada, K. Epigallocatechin-3-o-gallate disrupts stress fibers and the contractile ring by reducing myosin regulatory light chain phosphorylation mediated through the target molecule 67 kda laminin receptor. Biochem. Biophys. Res. Commun. 2005, 333, 628-635. [CrossRef] [PubMed]

56. Shankar, S.; Suthakar, G.; Srivastava, R.K. Epigallocatechin-3-gallate inhibits cell cycle and induces apoptosis in pancreatic cancer. Front. Biosci. 2007, 12, 5039-5051. [CrossRef]

57. Hwang, Y.S.; Park, K.K.; Chung, W.Y. Epigallocatechin-3 gallate inhibits cancer invasion by repressing functional invadopodia formation in oral squamous cell carcinoma. Eur. J. Pharmacol. 2013, 715, 286-295. [CrossRef]

58. Olotu, F.A.; Agoni, C.; Adeniji, E.; Abdullahi, M.; Soliman, M.E. Probing gallate-mediated selectivity and high-affinity binding of epigallocatechin gallate: A way-forward in the design of selective inhibitors for anti-apoptotic bcl-2 proteins. Appl. Biochem. Biotechnol. 2018, 29, 1-20. [CrossRef]

59. Shin, S.; Kim, M.K.; Jung, W.; Chong, Y. (-)-epigallocatechin gallate derivatives reduce the expression of both urokinase plasminogen activator and plasminogen activator inhibitor-1 to inhibit migration, adhesion, and invasion of mda-mb-231 cells. Phytother. Res. 2018, 32, 2086-2096. [CrossRef]

60. Shi, J.; Liu, F.; Zhang, W.; Liu, X.; Lin, B.; Tang, X. Epigallocatechin-3-gallate inhibits nicotine-induced migration and invasion by the suppression of angiogenesis and epithelial-mesenchymal transition in non-small cell lung cancer cells. Oncol. Rep. 2015, 33, 2972-2980. [CrossRef]

61. Umeda, D.; Yano, S.; Yamada, K.; Tachibana, H. Green tea polyphenol epigallocatechin-3-gallate signaling pathway through 67-kda laminin receptor. J. Biol. Chem. 2008, 283, 3050-3058. [CrossRef] [PubMed]

62. Jang, J.Y.; Lee, J.K.; Jeon, Y.K.; Kim, C.W. Exosome derived from epigallocatechin gallate treated breast cancer cells suppresses tumor growth by inhibiting tumor-associated macrophage infiltration and $\mathrm{m} 2$ polarization. BMC Cancer 2013, 13, 421. [CrossRef] [PubMed]

63. Borutinskaite, V.; Virksaite, A.; Gudelyte, G.; Navakauskiene, R. Green tea polyphenol egcg causes anti-cancerous epigenetic modulations in acute promyelocytic leukemia cells. Leuk. Lymphoma 2018, 59, 469-478. [CrossRef] [PubMed]

64. Ma, J.; Shi, M.; Li, G.; Wang, N.; Wei, J.; Wang, T.; Wang, Y. Regulation of id1 expression by epigallocatechin3gallate and its effect on the proliferation and apoptosis of poorly differentiated ags gastric cancer cells. Int. J. Oncol. 2013, 43, 1052-1058. [CrossRef] 
65. Lee, Y.H.; Kwak, J.; Choi, H.K.; Choi, K.C.; Kim, S.; Lee, J.; Jun, W.; Park, H.J.; Yoon, H.G. Egcg suppresses prostate cancer cell growth modulating acetylation of androgen receptor by anti-histone acetyltransferase activity. Int. J. Mol. Med. 2012, 30, 69-74. [PubMed]

66. Balasubramanian, S.; Adhikary, G.; Eckert, R.L. The bmi-1 polycomb protein antagonizes the (-)-epigallocatechin-3-gallate-dependent suppression of skin cancer cell survival. Carcinogenesis 2010, 31, 496-503. [CrossRef] [PubMed]

67. Takahashi, A.; Watanabe, T.; Mondal, A.; Suzuki, K.; Kurusu-Kanno, M.; Li, Z.; Yamazaki, T.; Fujiki, H.; Suganuma, M. Mechanism-based inhibition of cancer metastasis with (-)-epigallocatechin gallate. Biochem. Biophys. Res. Commun. 2014, 443, 1-6. [CrossRef]

68. Chen, H.; Landen, C.N.; Li, Y.; Alvarez, R.D.; Tollefsbol, T.O. Epigallocatechin gallate and sulforaphane combination treatment induce apoptosis in paclitaxel-resistant ovarian cancer cells through htert and bcl-2 down-regulation. Exp. Cell Res. 2013, 319, 697-706. [CrossRef]

69. Basu, A.; Haldar, S. Combinatorial effect of epigallocatechin-3-gallate and trail on pancreatic cancer cell death. Int. J. Oncol. 2009, 34, 281-286. [CrossRef]

70. Belguise, K.; Guo, S.; Sonenshein, G.E. Activation of foxo3a by the green tea polyphenol epigallocatechin3-gallate induces estrogen receptor alpha expression reversing invasive phenotype of breast cancer cells. Cancer Res. 2007, 67, 5763-5770. [CrossRef]

71. Harper, C.E.; Patel, B.B.; Wang, J.; Eltoum, I.A.; Lamartiniere, C.A. Epigallocatechin-3-gallate suppresses early stage, but not late stage prostate cancer in tramp mice: Mechanisms of action. Prostate 2007, 67, 1576-1589. [CrossRef]

72. Deb, G.; Thakur, V.S.; Limaye, A.M.; Gupta, S. Epigenetic induction of tissue inhibitor of matrix metalloproteinase-3 by green tea polyphenols in breast cancer cells. Mol. Carcinog. 2015, 54, 485-499. [CrossRef]

73. Moses, M.A.; Henry, E.C.; Ricke, W.A.; Gasiewicz, T.A. The heat shock protein 90 inhibitor, (-)-epigallocatechin gallate, has anticancer activity in a novel human prostate cancer progression model. Cancer Prev. Res. 2015, 8, 249-257. [CrossRef] [PubMed]

74. Kumazoe, M.; Sugihara, K.; Tsukamoto, S.; Huang, Y.; Tsurudome, Y.; Suzuki, T.; Suemasu, Y.; Ueda, N.; Yamashita, S.; Kim, Y.; et al. 67-kda laminin receptor increases cgmp to induce cancer-selective apoptosis. J. Clin. Investig. 2013, 123, 787-799. [CrossRef]

75. Vahora, H.; Khan, M.A.; Alalami, U.; Hussain, A. The potential role of nitric oxide in halting cancer progression through chemoprevention. J. Cancer Prev. 2016, 21, 1-12. [CrossRef]

76. Surh, Y.J.; Chun, K.S.; Cha, H.H.; Han, S.S.; Keum, Y.S.; Park, K.K.; Lee, S.S. Molecular mechanisms underlying chemopreventive activities of anti-inflammatory phytochemicals: Down-regulation of cox-2 and inos through suppression of nf-kappa b activation. Mutat. Res. 2001, 480-481, 243-268. [CrossRef]

77. Hayakawa, S.; Saito, K.; Miyoshi, N.; Ohishi, T.; Oishi, Y.; Miyoshi, M.; Nakamura, Y. Anti-cancer effects of green tea by either anti- or pro- oxidative mechanisms. Asian Pac. J. Cancer Prev. 2016, 17, 1649-1654. [CrossRef]

78. Dhakshinamoorthy, S.; Porter, A.G. Nitric oxide-induced transcriptional up-regulation of protective genes by nrf2 via the antioxidant response element counteracts apoptosis of neuroblastoma cells. J. Biol. Chem. 2004, 279, 20096-20107. [CrossRef]

79. Li, Y.J.; Wu, S.L.; Lu, S.M.; Chen, F.; Guo, Y.; Gan, S.M.; Shi, Y.L.; Liu, S.; Li, S.L. (-)-epigallocatechin-3-gallate inhibits nasopharyngeal cancer stem cell self-renewal and migration and reverses the epithelial-mesenchymal transition via nf-kappab p65 inactivation. Tumour. Biol. 2015, 36, 2747-2761. [CrossRef]

80. He, L.; Zhang, E.; Shi, J.; Li, X.; Zhou, K.; Zhang, Q.; Le, A.D.; Tang, X. (-)-epigallocatechin-3-gallate inhibits human papillomavirus (hpv)-16 oncoprotein-induced angiogenesis in non-small cell lung cancer cells by targeting hif-1alpha. Cancer Chemother. Pharmacol. 2013, 71, 713-725. [CrossRef]

81. Yamada, S.; Tsukamoto, S.; Huang, Y.; Makio, A.; Kumazoe, M.; Yamashita, S.; Tachibana, H. Epigallocatechin-3-O-gallate up-regulates microrna-let-7b expression by activating $67-\mathrm{kda}$ laminin receptor signaling in melanoma cells. Sci. Rep. 2016, 6, 19225. [CrossRef] [PubMed]

82. Wang, H.; Bian, S.; Yang, C.S. Green tea polyphenol egcg suppresses lung cancer cell growth through upregulating mir-210 expression caused by stabilizing hif-1alpha. Carcinogenesis 2011, 32, 1881-1889. [CrossRef] [PubMed] 
83. Urusova, D.V.; Shim, J.H.; Kim, D.J.; Jung, S.K.; Zykova, T.A.; Carper, A.; Bode, A.M.; Dong, Z. Epigallocatechin-gallate suppresses tumorigenesis by directly targeting pin1. Cancer Prev. Res. 2011, 4, 1366-1377. [CrossRef] [PubMed]

84. Qin, J.; Chen, H.G.; Yan, Q.; Deng, M.; Liu, J.; Doerge, S.; Ma, W.; Dong, Z.; Li, D.W. Protein phosphatase-2a is a target of epigallocatechin-3-gallate and modulates p53-bak apoptotic pathway. Cancer Res. 2008, 68, 4150-4162. [CrossRef] [PubMed]

85. Toden, S.; Tran, H.M.; Tovar-Camargo, O.A.; Okugawa, Y.; Goel, A. Epigallocatechin-3-gallate targets cancer stem-like cells and enhances 5-fluorouracil chemosensitivity in colorectal cancer. Oncotarget 2016, 7, 16158-16171. [CrossRef] [PubMed]

86. Tsukamoto, S.; Huang, Y.; Umeda, D.; Yamada, S.; Yamashita, S.; Kumazoe, M.; Kim, Y.; Murata, M.; Yamada, K.; Tachibana, H. 67-kda laminin receptor-dependent protein phosphatase 2a (pp2a) activation elicits melanoma-specific antitumor activity overcoming drug resistance. J. Biol. Chem. 2014, 289, 32671-32681. [CrossRef] [PubMed]

87. Saldanha, S.N.; Kala, R.; Tollefsbol, T.O. Molecular mechanisms for inhibition of colon cancer cells by combined epigenetic-modulating epigallocatechin gallate and sodium butyrate. Exp. Cell Res. 2014, 324, 40-53. [CrossRef]

88. Zhang, Y.; Wang, S.X.; Ma, J.W.; Li, H.Y.; Ye, J.C.; Xie, S.M.; Du, B.; Zhong, X.Y. Egcg inhibits properties of glioma stem-like cells and synergizes with temozolomide through downregulation of p-glycoprotein inhibition. J. Neurooncol. 2015, 121, 41-52. [CrossRef]

89. Suzuki, Y.; Isemura, M. Binding interaction between (-)-epigallocatechin gallate causes impaired spreading of cancer cells on fibrinogen. Biomed. Res. 2013, 34, 301-308. [CrossRef]

90. Tachibana, H.; Koga, K.; Fujimura, Y.; Yamada, K. A receptor for green tea polyphenol egcg. Nat. Struct. Mol. Biol. 2004, 11, 380-381. [CrossRef]

91. Lee, S.H.; Nam, H.J.; Kang, H.J.; Kwon, H.W.; Lim, Y.C. Epigallocatechin-3-gallate attenuates head and neck cancer stem cell traits through suppression of notch pathway. Eur. J. Cancer 2013, 49, 3210-3218. [CrossRef] [PubMed]

92. Adachi, S.; Nagao, T.; Ingolfsson, H.I.; Maxfield, F.R.; Andersen, O.S.; Kopelovich, L.; Weinstein, I.B. The inhibitory effect of (-)-epigallocatechin gallate on activation of the epidermal growth factor receptor is associated with altered lipid order in ht29 colon cancer cells. Cancer Res. 2007, 67, 6493-6501. [CrossRef] [PubMed]

93. Duhon, D.; Bigelow, R.L.; Coleman, D.T.; Steffan, J.J.; Yu, C.; Langston, W.; Kevil, C.G.; Cardelli, J.A. The polyphenol epigallocatechin-3-gallate affects lipid rafts to block activation of the c-met receptor in prostate cancer cells. Mol. Carcinog. 2010, 49, 739-749. [CrossRef]

94. Tabuchi, M.; Hayakawa, S.; Honda, E.; Ooshima, K.; Itoh, T.; Yoshida, K.; Park, A.M.; Higashino, H.; Isemura, M.; Munakata, H. Epigallocatechin-3-gallate suppresses transforming growth factor-beta signaling by interacting with the transforming growth factor-beta type ii receptor. World J. Exp. Med. 2013, 3, 100-107. [CrossRef]

95. Wubetu, G.Y.; Shimada, M.; Morine, Y.; Ikemoto, T.; Ishikawa, D.; Iwahashi, S.; Yamada, S.; Saito, Y.; Arakawa, Y.; Imura, S. Epigallocatechin gallate hinders human hepatoma and colon cancer sphere formation. J. Gastroenterol. Hepatol. 2016, 31, 256-264. [CrossRef] [PubMed]

96. Punathil, T.; Tollefsbol, T.O.; Katiyar, S.K. Egcg inhibits mammary cancer cell migration through inhibition of nitric oxide synthase and guanylate cyclase. Biochem. Biophys. Res. Commun. 2008, 375, 162-167. [CrossRef]

97. Sen, T.; Dutta, A.; Chatterjee, A. Epigallocatechin-3-gallate (egcg) downregulates gelatinase-b (mmp-9) by involvement of fak/erk/nfkappab and ap-1 in the human breast cancer cell line mda-mb-231. Anticancer Drugs 2010, 21, 632-644. [CrossRef] [PubMed]

98. Singh, T.; Katiyar, S.K. Green tea polyphenol, (-)-epigallocatechin-3-gallate, induces toxicity in human skin cancer cells by targeting beta-catenin signaling. Toxicol. Appl. Pharmacol. 2013, 273, 418-424. [CrossRef] [PubMed]

99. Shankar, S.; Marsh, L.; Srivastava, R.K. Egcg inhibits growth of human pancreatic tumors orthotopically implanted in balb c nude mice through modulation of fkhrl1/foxo3a and neuropilin. Mol. Cell. Biochem. 2013, 372, 83-94. [CrossRef] [PubMed] 
100. Moradzadeh, M.; Hosseini, A.; Erfanian, S.; Rezaei, H. Epigallocatechin-3-gallate promotes apoptosis in human breast cancer $\mathrm{t} 47 \mathrm{~d}$ cells through down-regulation of pi3k/akt and telomerase. Pharmacol. Rep. 2017, 69, 924-928. [CrossRef] [PubMed]

101. Ketchart, W.; Smith, K.M.; Krupka, T.; Wittmann, B.M.; Hu, Y.; Rayman, P.A.; Doughman, Y.Q.; Albert, J.M.; Bai, X.; Finke, J.H.; et al. Inhibition of metastasis by hexim1 through effects on cell invasion and angiogenesis. Oncogene 2013, 32, 3829-3839. [CrossRef] [PubMed]

102. Lu, C.L.; Xu, J.; Yao, H.J.; Luo, K.L.; Li, J.M.; Wu, T.; Wu, G.Z. Inhibition of human 67-kda laminin receptor sensitizes multidrug resistance colon cancer cell line sw480 for apoptosis induction. Tumour. Biol. 2016, 37, 1319-1325. [CrossRef] [PubMed]

103. Montuori, N.; Selleri, C.; Risitano, A.M.; Raiola, A.M.; Ragno, P.; Del Vecchio, L.; Rotoli, B.; Rossi, G. Expression of the 67-kda laminin receptor in acute myeloid leukemia cells mediates adhesion to laminin and is frequently associated with monocytic differentiation. Clin. Cancer Res. 1999, 5, 1465-1472. [PubMed]

104. Yu, H.N.; Zhang, L.C.; Yang, J.G.; Das, U.N.; Shen, S.R. Effect of laminin tyrosine-isoleucine-glycineserine-arginine peptide on the growth of human prostate cancer (pc-3) cells in vitro. Eur. J. Pharmacol. 2009, 616, 251-255. [CrossRef] [PubMed]

105. Liu, L.; Sun, L.; Zhang, H.; Li, Z.; Ning, X.; Shi, Y.; Guo, C.; Han, S.; Wu, K.; Fan, D. Hypoxia-mediated up-regulation of mgr1-ag/37lrp in gastric cancers occurs via hypoxia-inducible-factor 1-dependent mechanism and contributes to drug resistance. Int. J. Cancer 2009, 124, 1707-1715. [CrossRef] [PubMed]

106. Pesapane, A.; Ragno, P.; Selleri, C.; Montuori, N. Recent advances in the function of the $67 \mathrm{kda}$ laminin receptor and its targeting for personalized therapy in cancer. Curr. Pharm. Des. 2017, 23, 4745-4757.

107. Pesapane, A.; Di Giovanni, C.; Rossi, F.W.; Alfano, D.; Formisano, L.; Ragno, P.; Selleri, C.; Montuori, N.; Lavecchia, A. Discovery of new small molecules inhibiting $67 \mathrm{kda}$ laminin receptor interaction with laminin and cancer cell invasion. Oncotarget 2015, 6, 18116-18133. [CrossRef]

108. Li, Y.; Li, D.; Chen, J.; Wang, S. A polysaccharide from pinellia ternata inhibits cell proliferation and metastasis in human cholangiocarcinoma cells by targeting of cdc42 and $67 \mathrm{kda}$ laminin receptor (lr). Int. J. Biol. Macromol. 2016, 93, 520-525. [CrossRef]

109. Fujimura, Y.; Sumida, M.; Sugihara, K.; Tsukamoto, S.; Yamada, K.; Tachibana, H. Green tea polyphenol egcg sensing motif on the 67-kda laminin receptor. PLOS ONE 2012, 7, e37942. [CrossRef]

110. Fujimura, Y.; Yamada, K.; Tachibana, H. A lipid raft-associated $67 \mathrm{kda}$ laminin receptor mediates suppressive effect of epigallocatechin-3-o-gallate on fcepsilonri expression. Biochem. Biophys. Res. Commun. 2005, 336, 674-681. [CrossRef]

111. Simons, K.; Ikonen, E. Functional rafts in cell membranes. Nature 1997, 387, 569-572. [CrossRef] [PubMed]

112. Xu, L.; Auzins, A.; Sun, X.; Xu, Y.; Harnischfeger, F.; Lu, Y.; Li, Z.; Chen, Y.H.; Zheng, W.; Liu, W. The synaptic recruitment of lipid rafts is dependent on cd19-pi3k module and cytoskeleton remodeling molecules. J. Leukoc. Biol. 2015, 98, 223-234. [CrossRef] [PubMed]

113. Varshney, P.; Yadav, V.; Saini, N. Lipid rafts in immune signalling: Current progress and future perspective. Immunology 2016, 149, 13-24. [CrossRef] [PubMed]

114. Simons, K.; Toomre, D. Lipid rafts and signal transduction. Nat. Rev. Mol. Cell. Biol. 2000, 1, 31-39. [CrossRef] [PubMed]

115. Pike, L.J. Growth factor receptors, lipid rafts and caveolae: An evolving story. Biochim. Biophys. Acta 2005, 1746, 260-273. [CrossRef] [PubMed]

116. Diluvio, G.; Del Gaudio, F.; Giuli, M.V.; Franciosa, G.; Giuliani, E.; Palermo, R.; Besharat, Z.M.; Pignataro, M.G.; Vacca, A.; d'Amati, G.; et al. Notch3 inactivation increases triple negative breast cancer sensitivity to gefitinib by promoting egfr tyrosine dephosphorylation and its intracellular arrest. Oncogenesis 2018, 7, 42. [CrossRef]

117. Pike, L.J.; Han, X.; Gross, R.W. Epidermal growth factor receptors are localized to lipid rafts that contain a balance of inner and outer leaflet lipids: A shotgun lipidomics study. J. Biol. Chem. 2005, 280, 26796-26804. [CrossRef] [PubMed]

118. Masuda, M.; Wakasaki, T.; Toh, S.; Shimizu, M.; Adachi, S. Chemoprevention of head and neck cancer by green tea extract: Egcg-the role of egfr signaling and "lipid raft". J. Oncol. 2011, 2011, 540148. [CrossRef]

119. Guo, T.; Xu, L.; Che, X.; Zhang, S.; Li, C.; Wang, J.; Gong, J.; Ma, R.; Fan, Y.; Hou, K.; et al. Formation of the igf1r/cav1/src tri-complex antagonizes trail-induced apoptosis in gastric cancer cells. Cell. Biol. Int. 2017, 41, 749-760. [CrossRef] 
120. Alawin, O.A.; Ahmed, R.A.; Ibrahim, B.A.; Briski, K.P.; Sylvester, P.W. Antiproliferative effects of gamma-tocotrienol are associated with lipid raft disruption in her2-positive human breast cancer cells. J. Nutr. Biochem. 2016, 27, 266-277. [CrossRef]

121. Sur, S.; Pal, D.; Roy, R.; Barua, A.; Roy, A.; Saha, P.; Panda, C.K. Tea polyphenols egcg and tf restrict tongue and liver carcinogenesis simultaneously induced by n-nitrosodiethylamine in mice. Toxicol. Appl. Pharmacol. 2016, 300, 34-46. [CrossRef]

122. Ma, Y.C.; Li, C.; Gao, F.; Xu, Y.; Jiang, Z.B.; Liu, J.X.; Jin, L.Y. Epigallocatechin gallate inhibits the growth of human lung cancer by directly targeting the egfr signaling pathway. Oncol. Rep. 2014, 31, 1343-1349. [CrossRef] [PubMed]

123. Filippi, A.; Picot, T.; Aanei, C.M.; Nagy, P.; Szollosi, J.; Campos, L.; Ganea, C.; Mocanu, M.M. Epigallocatechin-3-o-gallate alleviates the malignant phenotype in a-431 epidermoid and sk-br-3 breast cancer cell lines. Int. J. Food Sci. Nutr. 2018, 69, 584-597. [CrossRef] [PubMed]

124. Pike, L.J. Rafts defined: A report on the keystone symposium on lipid rafts and cell function. J. Lipid. Res. 2006, 47, 1597-1598. [CrossRef]

125. Kim, J.Y.; Wang, L.; Lee, J.; Ou, J.J. Hepatitis c virus induces the localization of lipid rafts to autophagosomes for its rna replication. J. Virol. 2017, 91. [CrossRef]

126. Rosenberger, C.M.; Brumell, J.H.; Finlay, B.B. Microbial pathogenesis: Lipid rafts as pathogen portals. Curr. Biol. 2000, 10, R823-R825. [CrossRef]

127. Guimaraes, A.J.; de Cerqueira, M.D.; Zamith-Miranda, D.; Lopez, P.H.; Rodrigues, M.L.; Pontes, B.; Viana, N.B.; DeLeon-Rodriguez, C.M.; Rossi, D.C.P.; Casadevall, A.; et al. Host membrane glycosphingolipids and lipid microdomains facilitate histoplasma capsulatum internalization by macrophages. Cell. Microbiol. 2018, e12976. [CrossRef] [PubMed]

128. Smart, E.J.; Graf, G.A.; McNiven, M.A.; Sessa, W.C.; Engelman, J.A.; Scherer, P.E.; Okamoto, T.; Lisanti, M.P. Caveolins, liquid-ordered domains, and signal transduction. Mol. Cell. Biol. 1999, 19, 7289-7304. [CrossRef]

129. Hwangbo, C.; Tae, N.; Lee, S.; Kim, O.; Park, O.K.; Kim, J.; Kwon, S.H.; Lee, J.H. Syntenin regulates tgf-beta1-induced smad activation and the epithelial-to-mesenchymal transition by inhibiting caveolinmediated tgf-beta type i receptor internalization. Oncogene 2016, 35, 389-401. [CrossRef] [PubMed]

130. Laurenzana, A.; Fibbi, G.; Chilla, A.; Margheri, G.; Del Rosso, T.; Rovida, E.; Del Rosso, M.; Margheri, F. Lipid rafts: Integrated platforms for vascular organization offering therapeutic opportunities. Cell. Mol. Life Sci. 2015, 72, 1537-1557. [CrossRef]

131. Mollinedo, F.; Gajate, C. Lipid rafts as major platforms for signaling regulation in cancer. Adv. Biol. Regul. 2015, 57, 130-146. [CrossRef] [PubMed]

132. Tai, Y.T.; Podar, K.; Catley, L.; Tseng, Y.H.; Akiyama, M.; Shringarpure, R.; Burger, R.; Hideshima, T.; Chauhan, D.; Mitsiades, N.; et al. Insulin-like growth factor-1 induces adhesion and migration in human multiple myeloma cells via activation of beta1-integrin and phosphatidylinositol 3'-kinase/akt signaling. Cancer Res. 2003, 63, 5850-5858.

133. Raghu, H.; Sodadasu, P.K.; Malla, R.R.; Gondi, C.S.; Estes, N.; Rao, J.S. Localization of upar and mmp-9 in lipid rafts is critical for migration, invasion and angiogenesis in human breast cancer cells. BMC Cancer 2010, 10, 647. [CrossRef] [PubMed]

134. Lacour, S.; Hammann, A.; Grazide, S.; Lagadic-Gossmann, D.; Athias, A.; Sergent, O.; Laurent, G.; Gambert, P.; Solary, E.; Dimanche-Boitrel, M.T. Cisplatin-induced cd95 redistribution into membrane lipid rafts of ht29 human colon cancer cells. Cancer Res. 2004, 64, 3593-3598. [PubMed]

135. George, K.S.; Wu, S. Lipid raft: A floating island of death or survival. Toxicol. Appl. Pharmacol. 2012, 259, 311-319.

136. Alves, A.C.S.; Dias, R.A.; Kagami, L.P.; das Neves, G.M.; Torres, F.C.; Eifler-Lima, V.L.; Carvalho, I.; de Miranda Silva, C.; Kawano, D.F. Beyond the "lock and key" paradigm: Targeting lipid rafts to induce the selective apoptosis of cancer cells. Curr. Med. Chem. 2018, 25, 2082-2104. [CrossRef]

137. Tsukamoto, S.; Hirotsu, K.; Kumazoe, M.; Goto, Y.; Sugihara, K.; Suda, T.; Tsurudome, Y.; Suzuki, T.; Yamashita, S.; Kim, Y.; et al. Green tea polyphenol egcg induces lipid-raft clustering and apoptotic cell death by activating protein kinase cdelta and acid sphingomyelinase through a $67 \mathrm{kda}$ laminin receptor in multiple myeloma cells. Biochem. J. 2012, 443, 525-534. [CrossRef] 
138. Mocanu, M.M.; Ganea, C.; Georgescu, L.; Varadi, T.; Shrestha, D.; Baran, I.; Katona, E.; Nagy, P.; Szollosi, J. Epigallocatechin 3-o-gallate induces $67 \mathrm{kda}$ laminin receptor-mediated cell death accompanied by downregulation of erbb proteins and altered lipid raft clustering in mammary and epidermoid carcinoma cells. J. Nat. Prod. 2014, 77, 250-257. [CrossRef]

139. Huang, Y.; Kumazoe, M.; Bae, J.; Yamada, S.; Takai, M.; Hidaka, S.; Yamashita, S.; Kim, Y.; Won, Y.; Murata, M.; et al. Green tea polyphenol epigallocatechin-o-gallate induces cell death by acid sphingomyelinase activation in chronic myeloid leukemia cells. Oncol. Rep. 2015, 34, 1162-1168. [CrossRef]

140. Yang, C.S.; Wang, H. Cancer preventive activities of tea catechins. Molecules 2016, 21, 1679. [CrossRef]

141. Luo, K.W.; Lung, W.Y.; Chun, X.; Luo, X.L.; Huang, W.R. Egcg inhibited bladder cancer t24 and 5637 cell proliferation and migration via pi3k/akt pathway. Oncotarget 2018, 9, 12261-12272. [CrossRef]

142. Velavan, B.; Divya, T.; Sureshkumar, A.; Sudhandiran, G. Nano-chemotherapeutic efficacy of (-)-epigallocatechin 3-gallate mediating apoptosis in a549cells: Involvement of reactive oxygen species mediated nrf2/keap1signaling. Biochem. Biophys. Res. Commun. 2018, 503, 1723-1731. [CrossRef] [PubMed]

143. Gu, J.J.; Qiao, K.S.; Sun, P.; Chen, P.; Li, Q. Study of egcg induced apoptosis in lung cancer cells by inhibiting pi3k/akt signaling pathway. Eur. Rev. Med. Pharmacol. Sci. 2018, 22, 4557-4563.

144. Wang, Y.Q.; Lu, J.L.; Liang, Y.R.; Li, Q.S. Suppressive effects of egcg on cervical cancer. Molecules 2018, 23, 2334. [CrossRef] [PubMed]

145. Britschgi, A.; Simon, H.U.; Tobler, A.; Fey, M.F.; Tschan, M.P. Epigallocatechin-3-gallate induces cell death in acute myeloid leukaemia cells and supports all-trans retinoic acid-induced neutrophil differentiation via death-associated protein kinase 2. Br. J. Haematol. 2010, 149, 55-64. [CrossRef] [PubMed]

146. Shammas, M.A.; Neri, P.; Koley, H.; Batchu, R.B.; Bertheau, R.C.; Munshi, V.; Prabhala, R.; Fulciniti, M.; Tai, Y.T.; Treon, S.P.; et al. Specific killing of multiple myeloma cells by (-)-epigallocatechin-3-gallate extracted from green tea: Biologic activity and therapeutic implications. Blood 2006, 108, 2804-2810. [CrossRef]

147. Kirschnek, S.; Paris, F.; Weller, M.; Grassme, H.; Ferlinz, K.; Riehle, A.; Fuks, Z.; Kolesnick, R.; Gulbins, E. Cd95-mediated apoptosis in vivo involves acid sphingomyelinase. J. Biol. Chem. 2000, 275, 27316-27323. [PubMed]

148. Garcia-Barros, M.; Paris, F.; Cordon-Cardo, C.; Lyden, D.; Rafii, S.; Haimovitz-Friedman, A.; Fuks, Z.; Kolesnick, R. Tumor response to radiotherapy regulated by endothelial cell apoptosis. Science 2003, 300, 1155-1159. [CrossRef]

149. Zhang, Y.; Mattjus, P.; Schmid, P.C.; Dong, Z.; Zhong, S.; Ma, W.Y.; Brown, R.E.; Bode, A.M.; Schmid, H.H. Involvement of the acid sphingomyelinase pathway in uva-induced apoptosis. J. Biol. Chem. 2001, 276, 11775-11782. [CrossRef]

150. Goni, F.M.; Alonso, A. Sphingomyelinases: Enzymology and membrane activity. FEBS Lett. 2002, 531, $38-46$. [CrossRef]

151. Morita, Y.; Perez, G.I.; Paris, F.; Miranda, S.R.; Ehleiter, D.; Haimovitz-Friedman, A.; Fuks, Z.; Xie, Z.; Reed, J.C.; Schuchman, E.H.; et al. Oocyte apoptosis is suppressed by disruption of the acid sphingomyelinase gene or by sphingosine-1-phosphate therapy. Nat. Med. 2000, 6, 1109-1114. [CrossRef] [PubMed]

152. Gulbins, E. Regulation of death receptor signaling and apoptosis by ceramide. Pharmacol. Res. 2003, 47, 393-399. [CrossRef]

153. Hueber, A.O.; Bernard, A.M.; Herincs, Z.; Couzinet, A.; He, H.T. An essential role for membrane rafts in the initiation of fas/cd95-triggered cell death in mouse thymocytes. EMBO Rep. 2002, 3, 190-196. [CrossRef] [PubMed]

154. Kischkel, F.C.; Hellbardt, S.; Behrmann, I.; Germer, M.; Pawlita, M.; Krammer, P.H.; Peter, M.E. Cytotoxicity-dependent apo-1 (fas/cd95)-associated proteins form a death-inducing signaling complex (disc) with the receptor. EMBO J. 1995, 14, 5579-5588. [CrossRef] [PubMed]

155. Grassme, H.; Cremesti, A.; Kolesnick, R.; Gulbins, E. Ceramide-mediated clustering is required for cd95-disc formation. Oncogene 2003, 22, 5457-5470. [CrossRef] [PubMed]

156. Gajate, C.; Mollinedo, F. The antitumor ether lipid et-18-och(3) induces apoptosis through translocation and capping of fas/cd95 into membrane rafts in human leukemic cells. Blood 2001, 98, 3860-3863. [CrossRef] [PubMed]

157. London, E. Ceramide selectively displaces cholesterol from ordered lipid domains (rafts): Implications for lipid raft structure and function. J. Biol. Chem. 2004, 279, 9997-10004. 
158. Cremesti, A.; Paris, F.; Grassme, H.; Holler, N.; Tschopp, J.; Fuks, Z.; Gulbins, E.; Kolesnick, R. Ceramide enables fas to cap and kill. J. Biol. Chem. 2001, 276, 23954-23961. [CrossRef]

159. Fanzo, J.C.; Lynch, M.P.; Phee, H.; Hyer, M.; Cremesti, A.; Grassme, H.; Norris, J.S.; Coggeshall, K.M.; Rueda, B.R.; Pernis, A.B.; et al. Cd95 rapidly clusters in cells of diverse origins. Cancer Biol. Ther. 2003, 2, 392-395. [CrossRef]

160. Wu, L.Y.; De Luca, T.; Watanabe, T.; Morre, D.M.; Morre, D.J. Metabolite modulation of hela cell response to enox2 inhibitors egcg and phenoxodiol. Biochim. Biophys. Acta 2011, 1810, 784-789. [CrossRef]

161. Kim, M.H.; Chung, J. Synergistic cell death by egcg and ibuprofen in du-145 prostate cancer cell line. Anticancer Res. 2007, 27, 3947-3956. [PubMed]

162. Tan, X.; Zhang, Y.; Jiang, B.; Zhou, D. Changes in ceramide levels upon catechins-induced apoptosis in lovo cells. Life Sci. 2002, 70, 2023-2029. [CrossRef]

163. Zhou, L.; Yang, F.; Li, G.; Huang, J.; Liu, Y.; Zhang, Q.; Tang, Q.; Hu, C.; Zhang, R. Coptisine induces apoptosis in human hepatoma cells through activating 67-kda laminin receptor/cgmp signaling. Front. Pharmacol. 2018, 9, 517. [CrossRef] [PubMed]

164. Kumazoe, M.; Kim, Y.; Bae, J.; Takai, M.; Murata, M.; Suemasu, Y.; Sugihara, K.; Yamashita, S.; Tsukamoto, S.; Huang, Y.; et al. Phosphodiesterase 5 inhibitor acts as a potent agent sensitizing acute myeloid leukemia cells to 67-kda laminin receptor-dependent apoptosis. FEBS Lett. 2013, 587, 3052-3057. [CrossRef] [PubMed]

165. Kumazoe, M.; Tsukamoto, S.; Lesnick, C.; Kay, N.E.; Yamada, K.; Shanafelt, T.D.; Tachibana, H. Vardenafil, a clinically available phosphodiesterase inhibitor, potentiates the killing effect of egcg on cll cells. Br. J. Haematol. 2015, 168, 610-613. [CrossRef] [PubMed]

166. Casaletto, J.B.; McClatchey, A.I. Spatial regulation of receptor tyrosine kinases in development and cancer. Nat. Rev. Cancer 2012, 12, 387-400. [CrossRef] [PubMed]

167. Brizuela, L.; Dayon, A.; Doumerc, N.; Ader, I.; Golzio, M.; Izard, J.C.; Hara, Y.; Malavaud, B.; Cuvillier, O. The sphingosine kinase-1 survival pathway is a molecular target for the tumor-suppressive tea and wine polyphenols in prostate cancer. FASEB J. 2010, 24, 3882-3894. [CrossRef] [PubMed]

168. Olivera, A.; Spiegel, S. Sphingosine-1-phosphate as second messenger in cell proliferation induced by pdgf and fcs mitogens. Nature 1993, 365, 557-560. [CrossRef] [PubMed]

169. Cuvillier, O.; Pirianov, G.; Kleuser, B.; Vanek, P.G.; Coso, O.A.; Gutkind, S.; Spiegel, S. Suppression of ceramide-mediated programmed cell death by sphingosine-1-phosphate. Nature 1996, 381, 800-803. [CrossRef] [PubMed]

170. Tsukamoto, S.; Kumazoe, M.; Huang, Y.; Lesnick, C.; Kay, N.E.; Shanafelt, T.D.; Tachibana, H. Sphk1 inhibitor potentiates the anti-cancer effect of egcg on leukaemia cells. Br. J. Haematol. 2017, 178, 155-158. [CrossRef] [PubMed]

171. Chakrabarty, S.; Ganguli, A.; Das, A.; Nag, D.; Chakrabarti, G. Epigallocatechin-3-gallate shows anti-proliferative activity in hela cells targeting tubulin-microtubule equilibrium. Chem. Biol. Interact. 2015, 242, 380-389. [CrossRef] [PubMed]

172. Shenouda, N.S.; Zhou, C.; Browning, J.D.; Ansell, P.J.; Sakla, M.S.; Lubahn, D.B.; Macdonald, R.S. Phytoestrogens in common herbs regulate prostate cancer cell growth in vitro. Nutr. Cancer 2004, 49, 200-208. [CrossRef] [PubMed]

173. Umeda, D.; Yano, S.; Yamada, K.; Tachibana, H. Involvement of 67-kda laminin receptor-mediated myosin phosphatase activation in antiproliferative effect of epigallocatechin-3-O-gallate at a physiological concentration on caco-2 colon cancer cells. Biochem. Biophys. Res. Commun. 2008, 371, 172-176. [CrossRef] [PubMed]

174. D’Avino, P.P.; Giansanti, M.G.; Petronczki, M. Cytokinesis in animal cells. Cold Spring Harb. Perspect. Biol. 2015, 7, a015834. [CrossRef] [PubMed]

175. Wang, Y.L. The mechanism of cortical ingression during early cytokinesis: Thinking beyond the contractile ring hypothesis. Trends Cell. Biol. 2005, 15, 581-588. [CrossRef]

176. Matsumura, F. Regulation of myosin ii during cytokinesis in higher eukaryotes. Trends Cell. Biol. 2005, 15, 371-377. [CrossRef]

177. Moussavi, R.S.; Kelley, C.A.; Adelstein, R.S. Phosphorylation of vertebrate nonmuscle and smooth muscle myosin heavy chains and light chains. Mol. Cell. Biochem. 1993, 127-128, 219-227. [CrossRef]

178. Scholey, J.M.; Taylor, K.A.; Kendrick-Jones, J. Regulation of non-muscle myosin assembly by calmodulin-dependent light chain kinase. Nature 1980, 287, 233-235. [CrossRef] 
179. Ikebe, M.; Koretz, J.; Hartshorne, D.J. Effects of phosphorylation of light chain residues threonine 18 and serine 19 on the properties and conformation of smooth muscle myosin. J. Biol. Chem. 1988, 263, 6432-6437.

180. Kawano, Y.; Fukata, Y.; Oshiro, N.; Amano, M.; Nakamura, T.; Ito, M.; Matsumura, F.; Inagaki, M.; Kaibuchi, K. Phosphorylation of myosin-binding subunit (mbs) of myosin phosphatase by rho-kinase in vivo. J. Cell. Biol. 1999, 147, 1023-1038. [CrossRef]

181. Negrutskii, B.S.; El'skaya, A.V. Eukaryotic translation elongation factor 1 alpha: Structure, expression, functions, and possible role in aminoacyl-trna channeling. Prog. Nucleic Acid Res. Mol. Biol. 1998, 60, 47-78. [PubMed]

182. Gangwani, L.; Mikrut, M.; Galcheva-Gargova, Z.; Davis, R.J. Interaction of zpr1 with translation elongation factor-1alpha in proliferating cells. J. Cell. Biol. 1998, 143, 1471-1484. [CrossRef] [PubMed]

183. Lamberti, A.; Caraglia, M.; Longo, O.; Marra, M.; Abbruzzese, A.; Arcari, P. The translation elongation factor 1a in tumorigenesis, signal transduction and apoptosis: Review article. Amino Acids 2004, 26, 443-448. [CrossRef] [PubMed]

184. Izawa, T.; Fukata, Y.; Kimura, T.; Iwamatsu, A.; Dohi, K.; Kaibuchi, K. Elongation factor-1 alpha is a novel substrate of rho-associated kinase. Biochem. Biophys. Res. Commun. 2000, 278, 72-78. [CrossRef] [PubMed]

185. Peterson, R.T.; Desai, B.N.; Hardwick, J.S.; Schreiber, S.L. Protein phosphatase 2a interacts with the 70-kda s6 kinase and is activated by inhibition of fkbp12-rapamycinassociated protein. Proc. Natl. Acad. Sci. USA 1999, 96, 4438-4442. [CrossRef]

186. Zhang, Q.; Claret, F.X. Phosphatases: The new brakes for cancer development? Enzym. Res. 2012, 2012, 659649. [CrossRef] [PubMed]

187. Kiss, A.; Becsi, B.; Kolozsvari, B.; Komaromi, I.; Kover, K.E.; Erdodi, F. Epigallocatechin-3-gallate and penta-o-galloyl-beta-d-glucose inhibit protein phosphatase-1. FEBS J. 2013, 280, 612-626. [CrossRef]

188. Kitano, K.; Nam, K.Y.; Kimura, S.; Fujiki, H.; Imanishi, Y. Sealing effects of (-)-epigallocatechin gallate on protein kinase $\mathrm{c}$ and protein phosphatase 2a. Biophys. Chem. 1997, 65, 157-164. [CrossRef]

189. Janssens, V.; Goris, J.; Van Hoof, C. Pp2a: The expected tumor suppressor. Curr. Opin. Genet. Dev. 2005, 15, 34-41. [CrossRef]

190. Stamenkovic, I.; Yu, Q. Merlin, a "magic" linker between extracellular cues and intracellular signaling pathways that regulate cell motility, proliferation, and survival. Curr. Protein Pept. Sci. 2010, 11, 471-484. [CrossRef]

191. Horiguchi, A.; Zheng, R.; Shen, R.; Nanus, D.M. Inactivation of the nf2 tumor suppressor protein merlin in du145 prostate cancer cells. Prostate 2008, 68, 975-984. [CrossRef] [PubMed]

192. Malhotra, A.; Shibata, Y.; Hall, I.M.; Dutta, A. Chromosomal structural variations during progression of a prostate epithelial cell line to a malignant metastatic state inactivate the nf2, nipsnap1, ugt2b17, and lpin2 genes. Cancer Biol. Ther. 2013, 14, 840-852. [CrossRef] [PubMed]

193. Petrilli, A.M.; Fernandez-Valle, C. Role of merlin/nf2 inactivation in tumor biology. Oncogene 2016, 35, 537-548. [CrossRef] [PubMed]

194. Ambros, V. Micrornas: Tiny regulators with great potential. Cell 2001, 107, 823-826. [CrossRef]

195. Johnson, S.M.; Grosshans, H.; Shingara, J.; Byrom, M.; Jarvis, R.; Cheng, A.; Labourier, E.; Reinert, K.L.; Brown, D.; Slack, F.J. Ras is regulated by the let-7 microrna family. Cell 2005, 120, 635-647. [CrossRef] [PubMed]

196. Schultz, J.; Lorenz, P.; Gross, G.; Ibrahim, S.; Kunz, M. Microrna let-7b targets important cell cycle molecules in malignant melanoma cells and interferes with anchorage-independent growth. Cell Res. 2008, 18, 549-557. [CrossRef] [PubMed]

197. Zedan, A.H.; Hansen, T.F.; Assenholt, J.; Pleckaitis, M.; Madsen, J.S.; Osther, P.J.S. Microrna expression in tumour tissue and plasma in patients with newly diagnosed metastatic prostate cancer. Tumour. Biol. 2018, 40, 1010428318775864. [CrossRef]

198. Zhou, H.; Chen, J.X.; Yang, C.S.; Yang, M.Q.; Deng, Y.; Wang, H. Gene regulation mediated by micrornas in response to green tea polyphenol egcg in mouse lung cancer. BMC Genom. 2014, 15 (Suppl. 11), S3. [CrossRef]

199. Pan, X.; Zhao, B.; Song, Z.; Han, S.; Wang, M. Estrogen receptor-alpha36 is involved in epigallocatechin3-gallate induced growth inhibition of er-negative breast cancer stem/progenitor cells. J. Pharmacol. Sci. 2016, 130, 85-93. [CrossRef] 
200. Jiang, P.; Xu, C.; Chen, L.; Chen, A.; Wu, X.; Zhou, M.; Haq, I.U.; Mariyam, Z.; Feng, Q. Egcg inhibits csc-like properties through targeting mir-485/cd44 axis in a549-cisplatin resistant cells. Mol. Carcinog. 2018, 57, 1835-1844. [CrossRef]

201. Nishimura, N.; Hartomo, T.B.; Pham, T.V.; Lee, M.J.; Yamamoto, T.; Morikawa, S.; Hasegawa, D.; Takeda, H.; Kawasaki, K.; Kosaka, Y.; et al. Epigallocatechin gallate inhibits sphere formation of neuroblastoma be(2)-c cells. Environ. Health Prev. Med. 2012, 17, 246-251. [CrossRef]

202. Kumazoe, M.; Takai, M.; Hiroi, S.; Takeuchi, C.; Yamanouchi, M.; Nojiri, T.; Onda, H.; Bae, J.; Huang, Y.; Takamatsu, K.; et al. Pde3 inhibitor and egcg combination treatment suppress cancer stem cell properties in pancreatic ductal adenocarcinoma. Sci. Rep. 2017, 7, 1917. [CrossRef] [PubMed]

203. Kumazoe, M.; Takai, M.; Bae, J.; Hiroi, S.; Huang, Y.; Takamatsu, K.; Won, Y.; Yamashita, M.; Hidaka, S.; Yamashita, S.; et al. Foxo3 is essential for cd44 expression in pancreatic cancer cells. Oncogene 2017, 36, 2643-2654. [CrossRef] [PubMed]

204. Eddy, S.F.; Kane, S.E.; Sonenshein, G.E. Trastuzumab-resistant her2-driven breast cancer cells are sensitive to epigallocatechin-3 gallate. Cancer Res. 2007, 67, 9018-9023. [CrossRef] [PubMed]

205. Farabegoli, F.; Govoni, M.; Ciavarella, C.; Orlandi, M.; Papi, A. A rxr ligand 6-oh-11-o-hydroxyphenanthrene with antitumour properties enhances (-)-epigallocatechin-3-gallate activity in three human breast carcinoma cell lines. BioMed Res. Int. 2014, 2014, 853086. [CrossRef]

206. Lugnier, C. Cyclic nucleotide phosphodiesterase (pde) superfamily: A new target for the development of specific therapeutic agents. Pharmacol. Ther. 2006, 109, 366-398. [CrossRef] [PubMed]

207. Lu, K.P.; Zhou, X.Z. The prolyl isomerase pin1: A pivotal new twist in phosphorylation signalling and disease. Nat. Rev. Mol. Cell Biol. 2007, 8, 904-916. [CrossRef] [PubMed]

208. Dominguez-Sola, D.; Dalla-Favera, R. Pinning down the c-myc oncoprotein. Nat. Cell Biol. 2004, 6, 288-289. [CrossRef] [PubMed]

209. Sears, R.C. The life cycle of c-myc: From synthesis to degradation. Cell Cycle 2004, 3, 1133-1137. [CrossRef] [PubMed]

210. Ryo, A.; Nakamura, M.; Wulf, G.; Liou, Y.C.; Lu, K.P. Pin1 regulates turnover and subcellular localization of beta-catenin by inhibiting its interaction with apc. Nat. Cell Biol. 2001, 3, 793-801. [CrossRef]

211. Bao, L.; Kimzey, A.; Sauter, G.; Sowadski, J.M.; Lu, K.P.; Wang, D.G. Prevalent overexpression of prolyl isomerase pin1 in human cancers. Am. J. Pathol. 2004, 164, 1727-1737. [CrossRef]

212. Ayala, G.; Wang, D.; Wulf, G.; Frolov, A.; Li, R.; Sowadski, J.; Wheeler, T.M.; Lu, K.P.; Bao, L. The prolyl isomerase pin1 is a novel prognostic marker in human prostate cancer. Cancer Res. 2003, 63, 6244-6251.

213. Moore, J.D.; Potter, A. Pin1 inhibitors: Pitfalls, progress and cellular pharmacology. Bioorg. Med. Chem. Lett. 2013, 23, 4283-4291. [CrossRef]

214. Hidaka, M.; Kosaka, K.; Tsushima, S.; Uchida, C.; Takahashi, K.; Takahashi, N.; Tsubuki, M.; Hara, Y.; Uchida, T. Food polyphenols targeting peptidyl prolyl cis/trans isomerase pin1. Biochem. Biophys. Res. Commun. 2018, 499, 681-687. [CrossRef]

215. Xi, L.; Wang, Y.; He, Q.; Zhang, Q.; Du, L. Interaction between pin1 and its natural product inhibitor epigallocatechin-3-gallate by spectroscopy and molecular dynamics simulations. Spectrochim. Acta A Mol. Biomol. Spectrosc 2016, 169, 134-143. [CrossRef]

216. Katsuno, Y.; Lamouille, S.; Derynck, R. Tgf-beta signaling and epithelial-mesenchymal transition in cancer progression. Curr. Opin. Oncol. 2013, 25, 76-84. [CrossRef] [PubMed]

217. Sun, L.; Diamond, M.E.; Ottaviano, A.J.; Joseph, M.J.; Ananthanarayan, V.; Munshi, H.G. Transforming growth factor-beta 1 promotes matrix metalloproteinase-9-mediated oral cancer invasion through snail expression. Mol. Cancer Res. 2008, 6, 10-20. [CrossRef]

218. Joseph, M.J.; Dangi-Garimella, S.; Shields, M.A.; Diamond, M.E.; Sun, L.; Koblinski, J.E.; Munshi, H.G. Slug is a downstream mediator of transforming growth factor-beta1-induced matrix metalloproteinase-9 expression and invasion of oral cancer cells. J. Cell. Biochem. 2009, 108, 726-736. [CrossRef]

219. Sinpitaksakul, S.N.; Pimkhaokham, A.; Sanchavanakit, N.; Pavasant, P. Tgf-beta1 induced mmp-9 expression in hnscc cell lines via smad/mlck pathway. Biochem. Biophys. Res. Commun. 2008, 371, 713-718. [CrossRef] [PubMed]

220. Chowdhury, A.; Nandy, S.K.; Sarkar, J.; Chakraborti, T.; Chakraborti, S. Inhibition of pro-/active mmp-2 by green tea catechins and prediction of their interaction by molecular docking studies. Mol. Cell. Biochem. 2017, 427, 111-122. [CrossRef] [PubMed] 
221. Sarkar, J.; Nandy, S.K.; Chowdhury, A.; Chakraborti, T.; Chakraborti, S. Inhibition of mmp-9 by green tea catechins and prediction of their interaction by molecular docking analysis. Biomed. Pharmacother. 2016, 84, 340-347. [CrossRef]

222. Schramm, L. Going green: The role of the green tea component egcg in chemoprevention. J. Carcinog. Mutagen. 2013, 4, 1000142. [CrossRef] [PubMed]

223. Riley, P.A. Epimutation and cancer: Carcinogenesis viewed as error-prone inheritance of epigenetic information. J. Oncol. 2018, 2018, 2645095. [CrossRef] [PubMed]

224. Huang, Z.; Huang, Q.; Ji, L.; Wang, Y.; Qi, X.; Liu, L.; Liu, Z.; Lu, L. Epigenetic regulation of active Chinese herbal components for cancer prevention and treatment: A follow-up review. Pharmacol. Res. 2016, 114, 1-12. [CrossRef] [PubMed]

225. Fang, M.Z.; Wang, Y.; Ai, N.; Hou, Z.; Sun, Y.; Lu, H.; Welsh, W.; Yang, C.S. Tea polyphenol (-)-epigallocatechin-3-gallate inhibits DNA methyltransferase and reactivates methylation-silenced genes in cancer cell lines. Cancer Res. 2003, 63, 7563-7570.

226. Pal, D.; Sur, S.; Roy, R.; Mandal, S.; Kumar Panda, C. Epigallocatechin gallate in combination with eugenol or amarogentin shows synergistic chemotherapeutic potential in cervical cancer cell line. J. Cell. Physiol. 2018, 234, 825-836. [CrossRef]

227. Oya, Y.; Mondal, A.; Rawangkan, A.; Umsumarng, S.; Iida, K.; Watanabe, T.; Kanno, M.; Suzuki, K.; Li, Z.; Kagechika, H.; et al. Down-regulation of histone deacetylase 4, -5 and -6 as a mechanism of synergistic enhancement of apoptosis in human lung cancer cells treated with the combination of a synthetic retinoid, am80 and green tea catechin. J. Nutr. Biochem. 2017, 42, 7-16. [CrossRef]

228. Zhang, Y.; Wang, X.; Han, L.; Zhou, Y.; Sun, S. Green tea polyphenol egcg reverse cisplatin resistance of a549/ddp cell line through candidate genes demethylation. Biomed. Pharmacother. 2015, 69, 285-290. [CrossRef]

229. Jin, H.; Chen, J.X.; Wang, H.; Lu, G.; Liu, A.; Li, G.; Tu, S.; Lin, Y.; Yang, C.S. Nnk-induced DNA methyltransferase 1 in lung tumorigenesis in a/j mice and inhibitory effects of (-)-epigallocatechin-3-gallate. Nutr. Cancer 2015, 67, 167-176. [CrossRef]

230. Liu, L.; Zuo, J.; Wang, G. Epigallocatechin-3-gallate suppresses cell proliferation and promotes apoptosis in ec9706 and eca109 esophageal carcinoma cells. Oncol. Lett. 2017, 14, 4391-4395. [CrossRef]

231. Le, C.T.; Leenders, W.P.J.; Molenaar, R.J.; van Noorden, C.J.F. Effects of the green tea polyphenol epigallocatechin-3-gallate on glioma: A critical evaluation of the literature. Nutr. Cancer 2018, 70, 317-333. [CrossRef] [PubMed]

232. Li, W.G.; Li, Q.H.; Tan, Z. Epigallocatechin gallate induces telomere fragmentation in hela and 293 but not in mrc-5 cells. Life Sci. 2005, 76, 1735-1746. [CrossRef] [PubMed]

233. Zhang, W.; Yang, P.; Gao, F.; Yang, J.; Yao, K. Effects of epigallocatechin gallate on the proliferation and apoptosis of the nasopharyngeal carcinoma cell line cne2. Exp. Ther. Med. 2014, 8, 1783-1788. [CrossRef]

234. Wang, X.; Hao, M.W.; Dong, K.; Lin, F.; Ren, J.H.; Zhang, H.Z. Apoptosis induction effects of egcg in laryngeal squamous cell carcinoma cells through telomerase repression. Arch. Pharm. Res. 2009, 32, 1263-1269. [CrossRef] [PubMed]

235. Sadava, D.; Whitlock, E.; Kane, S.E. The green tea polyphenol, epigallocatechin-3-gallate inhibits telomerase and induces apoptosis in drug-resistant lung cancer cells. Biochem. Biophys. Res. Commun. 2007, 360, $233-237$. [CrossRef]

236. Kuzuhara, T.; Sei, Y.; Yamaguchi, K.; Suganuma, M.; Fujiki, H. DNA and rna as new binding targets of green tea catechins. J. Biol. Chem. 2006, 281, 17446-17456. [CrossRef] [PubMed]

237. Kuzuhara, T.; Tanabe, A.; Sei, Y.; Yamaguchi, K.; Suganuma, M.; Fujiki, H. Synergistic effects of multiple treatments, and both DNA and rna direct bindings on, green tea catechins. Mol. Carcinog. 2007, 46, 640-645. [CrossRef]

(C) 2018 by the authors. Licensee MDPI, Basel, Switzerland. This article is an open access article distributed under the terms and conditions of the Creative Commons Attribution (CC BY) license (http://creativecommons.org/licenses/by/4.0/). 